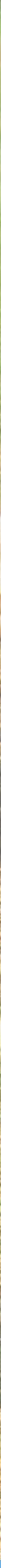

\title{
Inventarisatie van de effecten van uitloop pluimveehouderij op bodem-, water- en luchtkwaliteit
}

Auteurs: T.G.C.M. van Niekerk en F.R. Leenstra

Met medewerking van: B.F.J. Reuvekamp, F.E. de Buisonjé, A.J.A. Aarnink, H.H. Ellen,

P.W.G. Groot Koerkamp

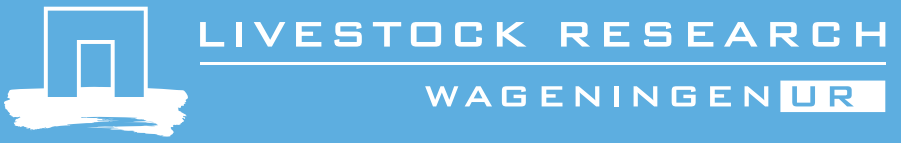





\section{Inventarisatie van de effecten van uitloop pluimveehouderij op bodem-, water- en luchtkwaliteit}


T.G.C.M. van Niekerk, F.R. Leenstra, met medewerking van B.F.J. Reuvekamp, F.E. de Buisonjé, A.J.A. Aarnink, H.H. Ellen, P.W.G. Groot Koerkamp, 2016. Inventarisatie van de effecten van uitloop pluimveehouderij op bodem-, water- en Luchtkwaliteit. Wageningen UR (University \& Research centre) Livestock Research, Livestock Research Rapport 954.

http://dx.doi.org/10.18174/385390

\section{Samenvatting NL}

Uit oogpunt van dierwelzijn krijgen leghennen in sommige houderijsystemen een uitloop. Aan een uitloop kunnen echter ook nadelen kleven, bijvoorbeeld ten aanzien van diergezondheid en milieubelasting. Deze deskstudie richt zich op de milieubelasting als gevolg van het aanbieden van een uitloop, waarbij specifiek wordt ingegaan op de emissies van ammoniak, geur en fijn stof, op de ophoping van mineralen in de bodem en op de uit- en afspoeling van mineralen uit de uitloop. Er worden diverse maatregelen besproken die mogelijk ongewenste milieu-effecten van plaatselijke overbemesting van de uitloop tegen kunnen gaan. In deze rapportage wordt tevens een vertaalslag gemaakt van de leghennenhouderij met uitloop naar eendenhouderij met uitloop.

\section{Summary UK}

To meet animal welfare demands, laying hens in some housing systems are provided with free range. However, free range can have disadvantages, e.g. with regards to animal health and environmental pollution. This desk study addresses the issue of environmental pollution as a consequence of providing free range, with special emphasis on emissions of ammonia, odour and fine dust, the accumulation of minerals in the soil and the leaching of minerals from the soil to open water. Several measures are discussed, that possibly prevent or reduce adverse effects on the environment of overmanuring of the free range. In this report also a translation is made from the laying hen sector to the keeping of ducks with free range.

(C) 2016 Wageningen UR Livestock Research, Postbus 338, 6700 AH Wageningen, T 0317483953 , E info.livestockresearch@wur.nl, www.wageningenUR.nl/livestockresearch. Livestock Research is onderdeel van Wageningen UR (University \& Research centre).

Livestock Research aanvaardt geen aansprakelijkheid voor eventuele schade voortvloeiend uit het gebruik van de resultaten van dit onderzoek of de toepassing van de adviezen.

Alle rechten voorbehouden. Niets uit deze uitgave mag worden vermenigvuldigd en/of openbaar gemaakt worden door middel van druk, fotokopie, microfilm of op welke wijze dan ook zonder voorafgaande toestemming van de uitgever of auteur.

De certificering volgens ISO 9001 door DNV onderstreept ons kwaliteitsniveau. Op als onze onderzoeksopdrachten zijn de Algemene Voorwaarden van de Animal Sciences Group van toepassing. Deze zijn gedeponeerd bij de Arrondissementsrechtbank Zwolle. 


\section{Inhoud}

$\begin{array}{ll}\text { Samenvatting } & \mathbf{5}\end{array}$

1

$\begin{array}{ll}\text { Inleiding } & \mathbf{7}\end{array}$

$\begin{array}{lll}1.1 & \text { Aanleiding } & 7\end{array}$

$\begin{array}{lll}1.2 & \text { Achtergrond } & 7\end{array}$

$\begin{array}{lll}1.3 & \text { Doel helpdeskvraag } & 7\end{array}$

$\begin{array}{lr}\text { Literatuurstudie } & 8\end{array}$

2.1 Omvang van de Nederlandse leghennensector en -bedrijven 8

2.2 Mineralenuitscheiding van leghennen 9

2.3 Wettelijke bepalingen ten aanzien van uitloop voor leghennen 9

2.3.1 Milieunormen 9

2.3.2 Houderijnormen voor uitloop in EU richtlijnen 10

2.3.3 Overdekte uitloop 11

$\begin{array}{lll}2.4 & \text { Benutting uitloop } & 11\end{array}$

2.5 Mineralenproductie in de buitenuitloop $\quad 12$

$\begin{array}{lll}2.6 & \text { Emissies in de buitenuitloop } & 17\end{array}$

2.6.1 Ammoniakemissie in de uitloop 18

2.6.2 Geur- en fijnstofemmisie in de uitloop 19

2.6.3 Methaan en lachgas $\quad 19$

2.7 Vergelijking milieueffecten uitloop leghennen met vroegere eendenhouderij 19

2.8 Mogelijkheden ter reductie ongewenste effecten $\quad 21$

2.8.1 Lager mineralengehalte in de mest realiseren $\quad 21$

2.8.2 Gelijkmatigere verdeling van de mest over de uitloop $\quad 21$

2.8.3 Verzameling van mest in een apart deel en het van daaruit weghalen en afvoeren

2.8.4 Maatregelen tegen uit- en afspoeling van mineralen 23

2.8.5 Gebruik en afmetingen van de uitloop $\quad 25$ 



\section{Samenvatting}

Uit oogpunt van dierwelzijn krijgen leghennen in sommige houderijsystemen een uitloop. Aan een uitloop kunnen echter ook nadelen kleven, bijvoorbeeld ten aanzien van diergezondheid en milieubelasting. Wat betreft diergezondheid is er met name discussie over de extra risico's van uitloop voor besmettingen met laag-pathogeen AI (aviaire influenza). Deze deskstudie richt zich op de milieubelasting als gevolg van het aanbieden van een uitloop, waarbij specifiek wordt ingegaan op de emissies van ammoniak, geur en fijn stof, op de ophoping van mineralen in de bodem en op de uit- en afspoeling van mineralen uit de uitloop. In deze rapportage wordt tevens een vertaalslag gemaakt van de leghennenhouderij met uitloop naar eendenhouderij met uitloop. In het kader van de mestregelgeving is medio jaren 90 besloten om eenden in stallen te gaan houden (in plaats van buiten) vanwege de bodem- en milieubelasting en diergezondheidsrisico's.

De bemestingsnorm voor dierlijke mest is in Nederland vastgesteld op $170 \mathrm{~kg}$ stikstof per hectare en 55-100 kg $\mathrm{P}_{2} \mathrm{O}_{5}$ per hectare, afhankelijk van bouwland of grasland en van de fosfaattoestand van de bodem (Meststoffenwet en daarbij behorende uitvoeringsregelingen). Per bedrijf mag dus over het totale oppervlakte aan landbouwgrond gerekend deze norm voor dierlijke mest niet overschreden worden. De regelgeving spreekt zich niet uit over een verplichting de mest egaal over het perceel te verdelen.

De excretie van stikstof en fosfaat bij leghennen is $780 \mathrm{~g} \mathrm{~N}$ en $400 \mathrm{~g}$ fosfaat/hen/jaar voor gangbare hennen en $920 \mathrm{~g} \mathrm{~N}$ en $450 \mathrm{~g}$ fosfaat/hen/jaar voor biologische hennen. In het

Landbouwkwaliteitsbesluit wordt voor biologische hennen een N-productie in de mest van 371

$\mathrm{g} /$ hen/jaar aangenomen. Dit lagere getal is te verklaren als gerekend wordt met een verlies aan $\mathrm{N}$ van $50 \%$ via vluchtige componenten als ammoniak. In hoeverre dit juist is, is niet bekend. Uit de verhouding tussen $\mathrm{N}$ en fosfaatgehalte van de mest en de bemestingsnormen is te constateren, dat de fosfaatnorm meer beperkend is dan de stikstofnorm voor de hoeveelheid mest in de uitloop.

Er zijn in Nederland twee soorten leghennenbedrijven waarbij vrije uitloop verplicht is: ten eerste alle biologische (en biologisch-dynamische) bedrijven en ten tweede de reguliere bedrijven met uitloop, ook wel Freilandbedrijven genoemd. In de uitloop dienen hennen minimaal $4 \mathrm{~m}^{2}$ per kip te krijgen, hetgeen overeen komt met 2500 legkippen per hectare. De bemestingsnorm van $170 \mathrm{~kg} \mathrm{~N} / \mathrm{ha}$ uit dierlijke mest wordt bereikt door de jaarlijkse mestproductie van 230 (CBS-gegevens), dan wel 400 (gegevens Landbouwkwaliteitsbesluit) leghennen. Voor fosfaat wordt de hoogste norm van $100 \mathrm{~kg}$ uit dierlijke mest bereikt met 250 hennen (gangbaar) of 222 hennen (biologisch). Voor een stal met uitloop betekent dit, dat bij een aantal van 2500 hennen/ha slechts ca. $10 \%$ van de mest, die geproduceerd wordt, in de uitloop terecht mag komen, om overbemesting van de uitloop te voorkomen. Daarbij is uitgegaan van een uniforme verdeling van de mest over het totale oppervlak van de uitloop en dat er begroeiing aanwezig is om de meststoffen op te nemen. In de praktijk zijn weinig uitlopen begroeid en blijven de hennen doorgaans dicht bij de stal. De bodembelasting met stikstof en fosfaat dicht bij de stal zal dus aanzienlijk hoger zijn dan de bemestingsnormen.

De uitloop is gemiddeld over het jaar 8 uur per dag en dus een derde deel van de tijd toegankelijk voor de hennen. De benutting van de uitloop door leghennen is zeer variabel en sterk afhankelijk van de inrichting en beschutting die de hennen er vinden. Ook het type dier en het jaargetijde speelt een rol. Bij kleine koppels (max. 1000 hennen) kan gemiddeld meer dan 30\% van de hennen buiten zijn. Bij grote koppels leghennen (10.000 en meer hennen) ligt het gebruik van de uitloop doorgaans veel lager. Afhankelijk van de geboden beschutting in de uitloop, maken bij grote koppels 3 tot $15 \%$ van de hennen gebruik van de uitloop (gemiddeld gemeten over de periode dat de uitloop beschikbaar is, hetgeen doorgaans vanaf 10.00-12.00 uur 's morgens tot zonsondergang is).

Gemiddeld hebben vrije uitloopbedrijven in Nederland een omvang van 27 duizend hennen, verdeeld in groepen van 6000 hennen. Biologische bedrijven hebben gemiddeld 13 duizend hennen, verdeeld in groepen van 3000 hennen. Bij deze omvang is te verwachten dat ongeveer $15 \%$ van de hennen de uitloop gebruikt. Aangezien de uitloop een derde deel van de dag toegankelijk is, betekent dit over 24 
uur gemeten een gebruik van 5\%. Bij een evenredige mestproductie over het etmaal heen zou dan $5 \%$ van de mest in de uitloop terecht komen. Het gebruik van de uitloop (aantal hennen, dat in de uitloop komt en de mate waarin de gehele uitloop door de hennen gebruikt wordt) kan verbeterd worden door verbetering van de inrichting van de uitloop en het management om de hennen te stimuleren er gebruik van te maken.

Omdat de hennen doorgaans dicht bij de stal blijven, wordt de bodem van uitlopen van legpluimvee, zeker in de nabijheid van de stal, meer dan formeel op bedrijfsniveau toegelaten, belast met mineralen uit dierlijke mest. Door een sterk wisselend en niet egaal gebruik van de uitloop is een exact getal niet te geven. Metingen wijzen echter uit dat dichtbij de stal 3 tot 40 maal de hoeveelheid stikstof uit dierlijke mest terecht komt, die formeel gemiddeld over de gehele bedrijfsoppervlakte aan landbouwgrond is toegestaan. Pluimveemest bevat relatief veel fosfaat. De fosfaatbelasting dichtbij de stal overschrijdt de normen minimaal in dezelfde mate, maar zeer waarschijnlijk meer. Daardoor is het risico op afspoelen van stikstof en fosfaat vanuit de uitloop rondom de stal naar het oppervlaktewater hoog, evenals het risico op 'lekken' van stikstof en fosfaat naar het grondwater. Geconcludeerd kan worden dat dichtbij de stal sprake is van overbemesting van de grond. Tot hoever van de stal dit nog geldt, is zeer wisselend en afhankelijk van gebruik van de uitloop en inrichting.

De uitloop heeft naar verwachting een zeer beperkte bijdrage aan de emissie van stof, geur, methaan en ammoniak van legpluimveebedrijven. Metingen aan uitstoot van ammoniak vanaf de uitloop geven aan dat deze circa $5 \%$ betreft van de uitstoot uit de legstal. Voor stof, methaan en geur zijn geen cijfers bekend.

Er zijn diverse maatregelen mogelijk om ongewenste milieueffecten van plaatselijke overbemesting van de uitloop tegen te gaan. Ze kunnen gegroepeerd worden naar hun aanpak:

A. Lager mineralengehalte in de mest realiseren door aanpassing van het voer.

B. Gelijkmatigere verdeling van de mest over de uitloop

C. Verzameling van mest in een apart deel van de uitloop en het van daaruit weghalen en afvoeren

D. Maatregelen tegen uit- en afspoeling van mineralen

E. Maatregelen om omzettingsprocessen tegen te gaan zodat geen of minder geur en ammoniak ontstaat en geen andere $\mathrm{N}$-vormige emissie ontstaat

Hierbij zal optie A naar verwachting het grote mineralenoverschot in de uitloop onvoldoende kunnen terugdringen. Optie B zal alleen voldoende effectief kunnen zijn bij gebruik van mobiele stallen. Tot nu toe zijn er geen gegevens beschikbaar over effectiviteit en kosten van mogelijke maatregelen om overmatige belasting van de bodem met mineralen bij uitloophouderij van leghennen te voorkomen. Maatregelen uit de categorieën A, B en E zijn naar verwachting minder effectief dan maatregelen uit de categorieën $C$ en $D$.

Het verkleinen van de uitloop, zal doorgaans niet leiden tot minder mest in de uitloop. Doordat meer bedrijven dan aan de eisen kunnen voldoen, zullen er meer bedrijven met uitloop komen, waardoor landelijk gezien het probleem van overbemesting zal toenemen. Verkleining van de uitloop heeft alleen zin als hiermee een volledige controle van de overbemesting mogelijk is. Dit betekent in de praktijk een verkleining tot een formaat dat overkapt kan worden en een volledig harde bodem heeft, waardoor de mest verzameld kan worden en overbelasting van de grond in de uitloop met mineralen niet meer aan de orde is.

De huidige uitloophouderij bij leghennen is slechts in beperkte mate te vergelijken met de uitloophouderij bij eenden, zoals die in de 90-er jaren van de vorige eeuw voorkwam. De eenden werden gedurende een groot deel van het jaar permanent en met de hele koppel buiten gehouden. Bij de leghennen is slechts een deel van de hennen buiten. Ook zijn de hennen een groot deel van het etmaal (met name de nachtperiode) allemaal binnen. De mineralenbelasting op de uitloop zal bij eenden daarom vele malen groter geweest zijn, dan op dit moment het geval is bij leghennen. Dit neemt echter niet weg dat een overbelasting van de uitloop met mineralen ook bij leghennen aanwezig is. 


\section{$1 \quad$ Inleiding}

\section{$1.1 \quad$ Aanleiding}

Uit oogpunt van dierwelzijn krijgen leghennen in sommige houderijsystemen een uitloop. Aan een uitloop kunnen echter ook nadelen kleven, bijvoorbeeld ten aanzien van diergezondheid en milieubelasting. Wat betreft diergezondheid is er met name discussie over de extra risico's van uitloop voor besmettingen met laag-pathogeen AI (aviaire influenza). Deze deskstudie richt zich op de milieubelasting als gevolg van het aanbieden van een uitloop, waarbij specifiek wordt ingegaan op de emissies van ammoniak, geur en fijnstof, op de ophoping van mineralen in de bodem en op de verliezen aan mineralen uit de uitloop. In deze rapportage wordt tevens een vertaalslag gemaakt van de leghennenhouderij met uitloop naar eendenhouderij met uitloop. In het kader van de mestregelgeving is medio jaren 90 namelijk besloten om eenden in stallen te gaan houden (in plaats van buiten) vanwege de bodem- en milieubelasting en diergezondheidsrisico's.

Bij het vaststellen van ammoniakemissiefactoren voor uitloophouderij in het kader van de Regeling ammoniak en veehouderij is geen extra factor vastgesteld voor de ammoniakemissie vanaf (buiten)uitlopen bij leghennen, aangezien deze verwaarloosbaar klein wordt geacht. Ook voor geur en fijnstof wordt geen aparte bijdrage van de uitloop in de milieuvergunning meegenomen.

In deze rapportage worden de verschillende milieuaspecten en de huidige stand van kennis ten aanzien van milieueffecten bij toepassing van een uitloop bij leghennen en eenden op een rij gezet. Dit rapport wordt als input gebruikt voor de discussie over toekomstperspectieven van de uitloophouderij.

\subsection{Achtergrond}

De achtergrond van dit rapport is een Kennis voor Beleid vraag in het kader van beleidsthema: Verduurzaming veehouderij (BO-Agro).

Gevraagd wordt om een inventarisatie van de effecten van uitloop pluimveehouderij op bodem-, water- en luchtkwaliteit (ammoniak, mineralen, geur, fijnstof, lachgas en methaan). Het gaat daarbij om de legpluimveehouderij met een buitenuitloop, ook wel met de Duitse benaming Freilandhouderij aangeduid, en de biologische legpluimveehouderij.

Daarnaast is gevraagd de situatie van de (biologische) legpluimveehouderij met buitenuitloop te vergelijken met de situatie in de eendenhouderij vóór de wettelijke verplichting tot eendenhouderij in stallen.

\subsection{Doel helpdeskvraag}

Het doel van deze Kennis voor Beleidvraag is het in kaart brengen van de milieueffecten van pluimveehouderij met buitenuitloop en van mogelijke mitigerende maatregelen. Dit is input voor de discussie over toekomstperspectieven van uitloophouderij. 


\section{$2 \quad$ Literaturstudie}

\subsection{Omvang van de Nederlandse leghennensector en -bedrijven}

Volgens cijfers uit het Koppel Informatiesysteem Pluimvee van het Productschap voor Pluimveevlees en Eieren (KIP-systeem) waren er medio 2013 in Nederland 33 miljoen bedrijfsmatig gehouden leghennen, gehuisvest op 893 bedrijven. Hiervan werd een klein gedeelte (bijna 5 miljoen hennen op 68 bedrijven) in verrijkte kooien en koloniehuisvesting gehouden. De rest betrof hennen in nietkooisystemen en dit waren ruim 28 miljoen hennen op 825 bedrijven (Tabel 1 ).

Van de ruim 28 miljoen hennen in alternatieve houderij worden er ruim 21 miljoen in scharrelsystemen gehouden. Dit zijn systemen, waarbij de hennen doorgaans wel een overdekte uitloop ter beschikking hebben, maar geen buitenuitloop. Een overdekte uitloop heeft een verharde bodem, waardoor geen uit- en afspoeling naar de omgeving plaatsvindt. Ook wordt de overdekte uitloop qua ruimte en dus ook qua emissie vaak tot de stal gerekend. Bij de vrije uitloop systemen en de biologische systemen hebben de hennen toegang tot een buitenuitloop. Het betreft hier in totaal ruim 5 miljoen vrije uitloop hennen en 1,7 miljoen biologische hennen. Gezamenlijk betreft het 316 bedrijven met 6,8 miljoen hennen, hetgeen 35\% van het totale aantal legpluimveebedrijven (incl. kooibedrijven) en $21 \%$ van het totaal aantal leghennen is (incl. kooihennen).

De gemiddelde bedrijfsgrootte (exclusief kooibedrijven) bedroeg in 201334 duizend hennen per bedrijf. Scharrelbedrijven zonder uitloop hebben doorgaans meer hennen per bedrijf, terwijl biologische legbedrijven kleinere aantallen dieren houden. Gemiddeld genomen heeft een bedrijf met uitloop (vrije uitloop of biologisch) zo'n 21 duizend hennen. Zo'n $10 \%$ van alle bedrijven (incl. kooibedrijven) heeft 10.000-20.000 hennen, 4\% heeft minder dan 10.000 hennen en $50 \%$ van de bedrijven heeft minimaal 50.000 hennen.

Omdat het merendeel van de in Nederland geproduceerde eieren naar Duitsland geëxporteerd wordt, houden de bedrijven zich aan de eisen die door de Duitse controle-organisatie KAT gesteld worden (KAT, 2011). Deze eisen houden in, dat voor scharrel en vrijen uitloop niet meer dan 6000 hennen per eenheid gehouden mogen worden en voor biologische henen niet meer dan 3000 hennen per eenheid. Bij stallen die meer dan dit maximum aantal dieren huisvesten, worden gazen afscheidingen aangebracht, waardoor kleinere eenheden worden gerealiseerd. De KAT stelt tevens dat deze afscheidingen ook in de uitloop moeten worden gerealiseerd.

\section{Tabel 1}

Aantallen bedrijven, aantallen hennen en aantallen hennen per bedrijf in niet-kooi huisvestingssystemen in Nederland.

\begin{tabular}{|c|c|c|c|}
\hline & 2012 & $\begin{array}{l}2013 * \\
\text { september }\end{array}$ & $\begin{array}{l}\text { Gemiddeld aantal } \\
\text { henen/bedrijf }\end{array}$ \\
\hline \multicolumn{4}{|l|}{ scharrel } \\
\hline aantal bedrijven & 521 & 499 & \\
\hline aantal hennen $* 1.000$ & 18.514 & 21.220 & 47,260 \\
\hline \multicolumn{4}{|l|}{ vrije uitloop } \\
\hline aantal bedrijven & 185 & 191 & \\
\hline aantal hennen $* 1.000$ & 4.456 & 5.115 & 26,780 \\
\hline \multicolumn{4}{|l|}{ biologisch } \\
\hline aantal bedrijven & 127 & 135 & \\
\hline aantal hennen $* 1.000$ & 1.439 & 1.716 & 12,711 \\
\hline \multicolumn{4}{|c|}{ Totaal in niet-kooisystemen } \\
\hline aantal bedrijven & 833 & 825 & \\
\hline aantal hennen $* 1.000$ & 24.409 & 28.050 & 34,000 \\
\hline
\end{tabular}

Bron: PVE, Koppel Informatiesysteem Pluimvee

*Gegevens over 2013 zijn voorlopige cijfers. 


\subsection{Mineralenuitscheiding van leghennen}

Bij leghennen is berekend wat de gemiddelde excretie van mineralen is. Daar wordt doorgaans de balansmethode voor gebruikt: de hoeveelheid mineralen die de hen via het voer krijgt minus de hoeveelheid mineralen, die in eieren en het lichaam van de hen worden vastgelegd (Bikker et al., 2013). Uit deze berekening volgt bij gangbare hennen een excretie via mest en urine (bij pluimvee niet te scheiden) van $780 \mathrm{~g} \mathrm{~N}$ per hen per jaar en van $400 \mathrm{~g}$ fosfaat per hen per jaar. Biologische hennen hebben een berekende excretie van $920 \mathrm{~g} \mathrm{~N}$ per hen per jaar en $450 \mathrm{~g}$ fosfaat per hen per jaar. Circa $76 \%$ van de $\mathrm{N}$ in de mest zit in ammoniumverbindingen (CBS 2012). Een deel van die ammoniumverbindingen zal na uitscheiding van de mest vervluchtigen als ammoniak. Een redelijke aanname is, dat ongeveer de helft van die ammoniumverbindingen uit leghennenmest vervluchtigd, echter afhankelijk van de omstandigheden rondom de mest. Die kunnen voor een keutel, die in de uitloop belandt, aanzienlijk verschillen van een keutel, die op de mestband belandt. In paragraaf 2.6 wordt ingegaan op de ammoniakemissie van de uitloop.

De Landbouwkwaliteitsregeling (2007) geeft in Bijlage 1 aan, dat voor het berekenen van het aantal dieren dat per ha gehouden mag worden, opdat de $\mathrm{N}$-gift per ha de $170 \mathrm{~kg} / \mathrm{jaar}$ uit dierlijke mest niet overschrijdt, bij biologische leghennen gerekend moet worden met een $\mathrm{N}$-uitscheiding via de mest van $371 \mathrm{~g} \mathrm{~N}$ per hen per jaar. Een dergelijke hoeveelheid komt ongeveer overeen met de totale hoeveelheid $\mathrm{N}$ in de mest conform de balansmethode minus de geschatte hoeveelheid $\mathrm{N}$, die via vervluchtigen verloren zou kunnen gaan.

\subsection{Wettelijke bepalingen ten aanzien van uitloop voor leghennen}

\subsubsection{Milieunormen}

Overbemesting van landbouwgrond veroorzaakt uitspoeling, afspoeling en ophoping van mineralen. Met name het nitraatgehalte in grondwater kan verhoogd worden en daarmee een risico vormen voor een te hoog nitraatgehalte in water voor menselijke consumptie.

De daadwerkelijke gehaltes in het grondwater zijn niet alleen afhankelijk van bemesting, maar worden ook beïnvloed door het type grond. In zandgebieden spoelen mineralen gemakkelijker uit naar het grondwater en zijn de nitraatgehalten in het ondiepe grondwater (5-15 m diepte) vaak hoger dan de streefwaarde. In de klei- en veengebieden vinden soms overschrijdingen van de streefwaarde plaats die vooral veroorzaakt worden door hoge natuurlijke gehalten van de desbetreffende stof (CBS, 2013).

Wereldwijd (Wereld Gezondheidsorganisatie, WHO), Europees (EU-Drinkwaterrichtlijn in 1980) en nationaal (Waterleidingwet) is voor nitraat een grenswaarde van $50 \mathrm{mg} / \mathrm{l}$ vastgesteld als maximaal toelaatbaar risico (MTR)-waarde voor water voor menselijke consumptie. Omdat in sommige gebieden in Nederland grondwater wordt gebruikt als bron voor drinkwater, moet dit volgens de EUNitraatrichtlijn aan deze MTR-waarde voldoen (CBS, 2013).

Voor fosfaat geldt dat het, normaal gesproken, niet uitspoelt naar het grondwater, zoals nitraat, maar wel kan afspoelen naar het oppervlaktewater. Bij fosfaatverzadigde gronden echter is zodanig veel fosfaat aanwezig, dat zoveel fosfaat naar het oppervlaktewater afspoelt dat op termijn in het bovenste grondwater (gemiddelde hoogste grondwaterstand; GHG) een fosforconcentratie van 0,15 mg/l wordt overschreden.

Net als voor stikstof is ook hier de soort grond bepalend. Er wordt al over een fosfaatverzadigde grond gesproken als 25\% van de bindingscapaciteit benut is; dit hoeft dus geen $100 \%$ te zijn (CBS, 2008). Met name bij sterk fosfaatverzadigde gronden ( $50 \%$ of meer van de bindingscapaciteit is verbruikt) met een hoge grondwaterstand, die in direct contact staan met oppervlaktewater, kan relatief veel fosfaat via afspoeling naar het oppervlaktewater verdwijnen, waardoor nadelige gevolgen voor waterecosystemen kunnen optreden (CBS, 2008).

In 1987 is begonnen met regelgeving om de overmatige fosfaatgiften die met dierlijke mest werden gegeven terug te dringen. Dit heeft ertoe geleid dat de fosfaatverzadiging van landbouwgronden geleidelijk is afgenomen. 
Met de invoering van het stelsel van gebruiksnormen voor fosfaat (Meststoffenwet) in 2006 is ook de gift van kunstmest onder de regelgeving gebracht (CBS, 2008).

De bemestingsnorm uit dierlijke mest is in Nederland vastgesteld op $170 \mathrm{~kg}$ stikstof per hectare en 55-100 kg $\mathrm{P}_{2} \mathrm{O}_{5}$ per hectare, afhankelijk van bouwland of grasland en van de fosfaattoestand van de bodem (zie o.a. Meststoffenwet, het Uitvoeringsbesluit Meststoffenwet, de Uitvoeringsregeling Meststoffenwet, het Besluit gebruik meststoffen).

\subsubsection{Houderijnormen voor uitloop in EU richtlijnen}

Voor leghennen zijn in Nederland twee soorten leghennenbedrijven waarbij vrije uitloop verplicht is. Voor niet-biologische hennen met uitloop gelden de regels voor de uitloop, zoals vastgelegd in Verordening (EEG) Nr. 1274/91 (EG, 1991). Daarin staat dat de uitloop in de open lucht ten minste moet voldoen aan de voorwaarden van artikel 4, lid 1, punt 3, onder b), ii), van Richtlijn 1999/74/EG, waarbij de bezetting op geen enkel moment meer bedraagt dan 2500 hennen per hectare terrein dat voor de hennen toegankelijk is, d.w.z. nooit meer dan één hen per $4 \mathrm{~m}^{2}$, en de uitloop zich niet verder uitstrekt dan $150 \mathrm{~m}$ van de dichtstbij gelegen uitgang van het gebouw; de uitloop mag zich tot $350 \mathrm{~m}$ van de dichtst bijgelegen uitgang van het gebouw uitstrekken, wanneer voldoende schuilplaatsen en drinkgoten in de zin van de genoemde bepaling gelijkmatig over de uitloopruimte verdeeld zijn, met een minimum van vier schuilplaatsen per hectare. Biologische (en biologisch-dynamische) bedrijven moeten voldoen aan de Europese Verordening (EG) Nr. 889/2008 (EG, 2008). In bijlage III van deze verordening staat dat leghennen een buitenruimte dienen te hebben van minimaal $4 \mathrm{~m}^{2}$, waarbij het maximum van $170 \mathrm{~kg} \mathrm{~kg} \mathrm{N/jaar} \mathrm{per} \mathrm{ha} \mathrm{niet} \mathrm{wordt} \mathrm{overschreden.} \mathrm{In} \mathrm{bijlage} \mathrm{IV} \mathrm{van} \mathrm{deze} \mathrm{verordening}$ wordt verder aangegeven dat het maximum aantal dieren per ha dat overeenkomt met $170 \mathrm{~kg} \mathrm{~N} / \mathrm{jaar}$ per ha 230 hennen bedraagt, als alle mest van de hennen op die ha terecht komt. Per hen wordt daarbij uitgegaan van een jaarlijkse uitscheiding van $0.74 \mathrm{~kg} \mathrm{~N}$. CBS (2012) gaat uit van een jaarlijkse uitscheiding per hen van $0.78 \mathrm{~kg} \mathrm{~N}$. Voor 230 hennen/ha betekent dat $179 \mathrm{~kg} \mathrm{~N}$. De Landbouwkwaliteitsregeling 2007 (bijlage I) noemt voor biologische leghennen een uitscheiding per hen per jaar van $0.371 \mathrm{~kg} \mathrm{~N}$. In dat geval kunnen 460 hennen per ha gehouden worden, als alle mest van die hennen op dat oppervlak terecht komt.

De bepaling van $4 \mathrm{~m}^{2}$ per kip komt overeen met 2500 legkippen per hectare. Voor een stal met uitloop betekent dit, dat bij een aantal van 2500 hennen/ha slechts 10,9\% (0.74 kg N/hen/jaar), dan wel $18,4 \%$ ( $0.371 \mathrm{~kg} \mathrm{~N} / \mathrm{hen} / \mathrm{jaar}$ ) van de mest die geproduceerd wordt, in de uitloop terecht mag komen, om overbemesting te voorkomen. In het eerste geval gaat het om de totale excretie, inclusief $\mathrm{N}$ in vluchtige componenten, in het tweede geval om mest waaruit de vluchtige $\mathrm{N}$-componenten niet zijn meegerekend.

Fosfaat vervluchtigt niet. De jaarlijkse fosfaatexcretie is $400 \mathrm{~g}$ per hen voor conventionele hennen en $450 \mathrm{~g}$ voor biologische hennen (Bikker et al, 2013). Bij een norm van $55 \mathrm{~kg}$ fosfaat per ha per jaar uit dierlijke mest betekent het, dat met de totale mestproductie van 138 (conventioneel) dan wel 122 (biologisch) hennen de limiet bereikt is. De norm van $100 \mathrm{~kg}$ fosfaat/ha wordt bereikt met de jaarlijkse mestproductie van 250 (222) hennen. De fosfaatnormen zijn dus eerder beperkend dan de stikstof normen als het gaat om de belasting van de uitloop. Om binnen de fosfaatnormen voor bemesting te blijven mag niet meer dan 5-10\% van de totale mestproductie van de 2500 hennen/ha in de uitloop terecht komen.

Daarbij is uitgegaan van een uniforme verdeling van de mest over het oppervlak van de uitloop en dat er begroeiing aanwezig is om de meststoffen op te nemen. In de praktijk zijn uitlopen vaak niet begroeid en is de verdeling van de hennen over de uitloop ook niet uniform. Lokaal, dicht bij de stal, zal meer mest gedeponeerd worden dan verder van de stal.

Voor de mestwetgeving wordt uitgegaan van het totale bedrijf, waarbij ook grond buiten de uitloop meegerekend wordt. Echter, voor de meeste pluimveebedrijven geldt, dat ze weinig extra landbouwgrond hebben. 


\subsubsection{Overdekte uitloop}

Een zeer groot deel van de Nederlandse eieren wordt geëxporteerd naar Duitsland en de productie moet daarom aan de KAT-regels voldoen (KAT, 2011). Voor houderijen met buitenuitloop stelt de KAT ook een overdekte uitloop, ook wel Wintergarten genoemd, verplicht. Het merendeel van de Nederlandse bedrijven met stallen met uitloop heeft daarom tevens een overdekte uitloop.

Een overdekte uitloop onderscheid zich op enkele punten van een buitenuitloop:

- de volledige overdekte uitloop is overkapt

- de buitenwanden zijn doorgaans over de lengte met windbreekgaas afgeschermd, dat oprolbaar is om de hennen toegang te verleden tot de buitenuitloop. De zijwanden kunnen uit diverse materialen bestaan (windbreekgaas, glas, steen)

- de boden van de overdekte uitloop is verhard, doorgaans voorzien van beton. Hierop is strooisel aangebracht.

Het klimaat in een overdekte uitloop is nagenoeg gelijk aan het buitenklimaat. Door de overkapping en afscherming met windbreekgaas, komt er nagenoeg geen neerslag in de overdekte uitloop, waardoor geen plasvorming optreedt en afspoeling naar het oppervlaktewater niet aan de orde is. Uitstroom van mineralen naar de bodem is door de verharde bodem niet mogelijk.

Enkele aparte varianten van een overdekte uitloop zijn te vinden bij de Rondeelstallen. Deze hebben de zogenaamde dagverblijven, die ook alleen door windbreekgaas afgeschermd worden van de buitenwereld. Deze dagverblijven zijn groter en door het lichtdoorlatende dak veel minder donker dan de overdekte uitlopen bij standaardstallen. De dagverblijven vormen door hun geïntegreerde ligging tussen de nachtverblijven meer een onderdeel van het gehele stalconcept.

De Rondeelstallen hebben ook een zogenaamde bosrand. Aanvankelijk was deze gebouwd als kleine buitenuitloop. De bodem was onverhard en de afscheiding bovenlangs werd gevormd door netten. Vanwege problemen met hygiëne is bij de nieuwere Rondeelstallen een verharde bodem in de bosrand aangebracht. Hierop werd een dikke laag zand en strooisel aangebracht. Als bovenafscheiding is een zeildoek aangebracht, dat naar keuze opgerold kan worden. Bij slecht weer kan aldus voorkomen worden dat regenwater in de bosrand komt. Deze nieuwe vormgeving van de bosrand komt meer overeen met de overdekte uitlopen, zoals die aan reguliere stallen gebouwd is.

\section{$2.4 \quad$ Benutting uitloop}

De benutting van de uitloop door leghennen is zeer variabel en sterk afhankelijk van de inrichting en beschutting die de hennen er vinden. Ook het type dier en het jaargetijde speelt een rol.

Dekker et al. (2010) onderzochten drie biologische legbedrijven met volièrehuisvesting (met koppelgrootte van minimaal 6.000 hennen) met verschillend ingerichte uitlopen. Hieruit kwam naar voren, dat het gebruik van de uitloop sterk bepaald wordt door de inrichting van de uitloop die zorgt voor beschutting voor de leghennen. Bij uitlopen met een goede inrichting en (vrij) veel beschutting waren overdag gemiddeld 14 tot $16 \%$ van de hennen buiten en kwam $6 \%$ van de hennen verder dan 25 meter van de stal (tabel 3). Bij een uitloop met een open inrichting en weinig beschutting waren overdag gemiddeld slechts $3 \%$ van de hennen buiten en deze bleven dichtbij de stal. Elbe et al.

(2005) onderzocht een koppel van 4500 leghennen en kwam tot een maximaal uitloopgebruik van $9,8 \%$, waarbij ook het grootste deel dichtbij de stal bleef (tabel 2 ).

\section{Tabel 2}

Gebruik* van de uitloop op 3 biologische bedrijven met verschillend ingerichte uitlopen (mate van beschutting) (Dekker et al., 2010).

\begin{tabular}{lllll} 
& $\%$ leghennen in de uitloop & & \\
Mate van beschutting & $0-10 \mathrm{~m}$ & $10-25 \mathrm{~m}$ & 6 & 16 \\
Veel & 7 & 2 & 6 & 14 \\
\hline Gemiddeld & 6 & 2 & 0 & 3 \\
\hline Weinig & 2 & 0 & hele uitloop \\
\hline
\end{tabular}

\footnotetext{
*tellingen elk half uur, over de gehele periode dat de uitloop beschikbaar was.
} 
Tabel 3

Uitloopgedrag van een koppel van 4500 leghennen (biologisch; uit: Elbe et al., 2005).

\begin{tabular}{llllll} 
Deel van de uitloop vanaf de stal $(\mathrm{m})$ & $0-6 \mathrm{~m}$ & $6-17 \mathrm{~m}$ & $\mathbf{1 7 - 5 4} \mathrm{m}$ & Totaal \\
Oppervlakte in $\left(\mathrm{m}^{2}\right)$ & 387 & 108 & 2144 & 2639 \\
\hline Hennen in het uitloopdeel: & & & & \\
\hline$\quad \quad$ aantal hennen & 196 & 108 & 138 & 442 \\
\hline$\quad$ \% van aantal buiten lopende hennen & 45 & 24 & 31 & 100 \\
\hline$\quad$ \% van het koppel & 4,4 & 2,4 & 3,1 & 9,8 \\
\hline Bezettingsdichtheid (hennen $\left./ \mathrm{m}^{2}\right)$ & 0,51 & 0,18 & 0,06 & 0,17 \\
\hline
\end{tabular}

EGTOP (2012) meldt dat in Denemarken een norm wordt aangehouden van $10 \%$ gebruik door de hennen (Johannsen, pers. comm. in EGTOP, 2012), maar uit Frans onderzoek zou blijken, dat tot 30\% van de hennen de uitloop gebruikt (Juin, pers. comm. in EGTOP, 2012). Er wordt verder niet aangegeven of dit indrukken zijn of gebaseerd op daadwerkelijke tellingen.

In Zwitserse onderzoek, dat door Zeelen (1995) gerapporteerd werd, kwam gemiddeld over de dag $49-68 \%$ van de hennen buiten, hetgeen in vergelijking met de hiervoor genoemde onderzoeken een zeer hoog percentage is. Waarschijnlijk komt dit door de kleine koppelgrootte van slechts 400 hennen. (Reichardt et al., 2004) rapporteerden dat kleinere koppels meer gebruik maken van de uitloop dan grote koppels. Bij een omvang van 500 hennen ging gemiddeld over de dag $31 \%$ van de hennen naar buiten, bij een omvang van 7.000 hennen $15,5 \%$, bij een omvang van 16.000 hennen $4 \%$ en bij een omvang van 20.000 ging 5,4\% naar buiten.

In tabel 4 staat het uitloopgebruik in relatie tot de afstand tot de stal, zoals door (Reichardt et al., 2004) bepaald. Deze cijfers komen redelijk overeen met die van Elbe et al. (2005). Reichardt et al. (2004) gaven ook een relatie aan tussen uitloopgebruik en buitentemperatuur. Bij kou en hitte is het gebruik lager dan bij gematigde temperaturen (tabel 5). Zij concludeerden dat hennen de uitloop bij voorkeur gebruiken bij temperaturen tussen 10 en $20^{\circ} \mathrm{C}$.

\section{Tabel 4}

Uitloopgebruik (in \% hennen dat buiten loopt $\pm S D$ ), in relatie tot de afstand tot de stal (Reichardt et al., 2004).

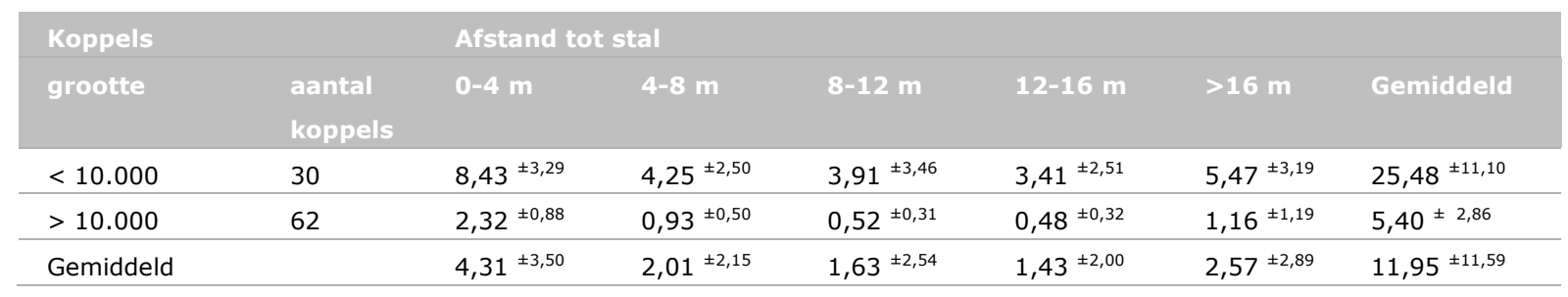

\section{Tabel 5}

Uitloopgebruik (\% hennen buiten \pm SD) in relatie tot buitentemperatuur (Reichardt et al., 2004).

\begin{tabular}{llll} 
Buitentemperatuur & $3-10^{\circ} \mathrm{C}$ & $10,1-20^{\circ} \mathrm{C}$ & $20,1-27^{\circ} \mathrm{C}$ \\
$\%$ hennen in uitloop & $6,64^{ \pm 2,69}$ & $17,32^{ \pm 15,53}$ & $15,10^{ \pm 13,16}$ \\
\hline
\end{tabular}

Doorgaans is de uitloop beschikbaar vanaf 10.00-12.00 uur 's morgens tot zonsondergang. Gemiddeld over het jaar is de uitloop ca. 8 uur per dag voor de hennen toegankelijk. Dat is 33,3\% van de dag, en $2 / 3$ van de lichtperiode van de hennen.

\subsection{Mineralenproductie in de buitenuitloop}

Kippen mesten in de uitloop en deponeren er op die manier mineralen. De plaats waar deze mineralen uitgescheiden worden is afhankelijk van hoeveel en waar de kippen zich in de uitloop begeven. Met een toenemend aantal hennen in de uitloop neemt ook de stikstof- en fosforbelasting in de uitloop toe. Afhankelijk van de inrichting van de uitloop maken meer of minder hennen gebruik van de uitloop. 
Een rijke inrichting zorgt er ook voor dat de hennen verder de uitloop in gaan, maar desondanks blijft het merendeel dichtbij de stal.

Reeds in 1995 berichtte Zeelen (1995) in het vakblad Pluimveehouderij over milieuaspecten van uitloop voor leghennen. In een Zwitsers onderzoek met 400 witte hennen in een volièresysteem met overdekte en buitenuitloop was het gebruik van de overdekte en buitenuitloop gemeten en was de hoeveelheid mest, die in de buitenuitloop geproduceerd werd, bepaald. De overdekte uitloop werd gebruikt als een 'slecht weer uitloop'. Bij extreem nat weer of bij bevroren bodem en sneeuw werden de dieren niet in de buitenuitloop gelaten. In oktober 1992, april en september 1993 werd gedurende 2 à 3 weken geteld hoeveel hennen in de stal, in de overdekte uitloop en in de buitenuitloop liepen. Om de mestproductie in de buitenuitloop te bepalen werden de hennen vervolgens gedurende 2 à 3 weken in de stal opgesloten. Het verschil in mestproductie in de stal tussen deze twee periodes werd aangemerkt als de hoeveelheid mest die in de uitloop geproduceerd werd. Uit de tellingen van het aantal hennen in de buitenuitloop kwam naar voren dat $49-68 \%$ van de hennen buiten liep. Van de geproduceerde mest kwam tijdens de uitloopperiode $15-30 \%$ in de buitenuitloop terecht. De onderzoekers berekenden vervolgens wat bij 100 dagen buitenuitloop per jaar omgerekend per hectare de mineralenbelasting was. Deze is in tabel 6 weergegeven. In deze tabel is tevens een calculatie gemaakt wat de mineralenuitstoot zou zijn bij gebruik van de uitloop gedurende 250 dagen per jaar en 365 dagen per jaar.

In het door Zeelen (1995) gerapporteerde onderzoek kwam van de geproduceerde mest tijdens de uitloopperiode $15-30 \%$ in de buitenuitloop terecht. Dit komt overeen met de bevindingen uit Frankrijk. Van de Franse bevindingen is verder niet bekend hoe groot het koppel was.

Een kanttekening bij dit onderzoek is, dat het uitgevoerd is aan een klein koppel leghennen. Kleine koppels hebben doorgaans een hoger uitloopgebruik dan grote koppels. Het gemeten gebruik van de uitloop is in ieder geval veel hoger dan onder Nederlandse omstandigheden wordt vastgesteld. Zeelen (1995) gaf ook aan dat bij grotere koppels de verschillen tussen de sterk en gering belaste delen van de uitloop groter zullen zijn bij grotere koppels, die zich doorgaans minder verspreiden over de uitloop.

\section{Tabel 6}

Berekende hoeveelheid mineralen in de buitenuitloop bij 100, 250 of 365 dagen uitloop per jaar, uitgaande van $15 \%$ mest in de buitenuitloop tijdens de uitloopperiode (Zeelen, 1995).

\begin{tabular}{|c|c|c|c|c|c|c|c|c|c|}
\hline \multirow{2}{*}{$\begin{array}{l}\text { Dagen uitloop per jaar } \\
\text { Mineralen (kg/ha/jaar) }\end{array}$} & \multicolumn{3}{|c|}{100} & \multicolumn{3}{|c|}{250} & \multicolumn{3}{|c|}{365} \\
\hline & Ntot & $\mathrm{P}_{2} \mathrm{O}_{5}$ & $\mathrm{~K}_{2} \mathrm{O}$ & Ntot & $\mathrm{P}_{2} \mathrm{O}_{5}$ & $\mathrm{~K}_{2} \mathrm{O}$ & Ntot & $\mathrm{P}_{2} \mathrm{O}_{5}$ & $\mathrm{~K}_{2} \mathrm{O}$ \\
\hline Gemiddeld & 130 & 84 & 44 & 325 & 210 & 110 & 475 & 307 & 161 \\
\hline Sterkst belaste deel & 292 & 285 & 135 & 730 & 713 & 338 & 1066 & 1040 & 493 \\
\hline Minst belaste deel & 19 & 12 & 7 & 48 & 30 & 18 & 69 & 44 & 26 \\
\hline
\end{tabular}

Zorn et al. (2004) onderzochten 17 uitlopen in Duitsland in de periode 2002-2003, namen grondmonsters van 0 tot $90 \mathrm{~cm}$ diep en onderzochten die op $\mathrm{N}$ en $\mathrm{P}$. Zij vonden een directe relatie tussen het gebruik van de uitloop en de hoogte van de concentraties $\mathrm{N}$ en $\mathrm{P}$ en de grond. Koppels van minder dan 2.000 hennen gebruikten de uitloop meer en daar werden ook hogere waarden gevonden dan bij koppels van meer dan 10.000 hennen. In de nabijheid van de stal werden hogere $\mathrm{N}$ concentraties gemeten dan verder van de stal af (tabel 7). Significant hogere P-waarden als gevolg van uitloopgebruik waren slechts gedeeltelijk meetbaar, waarschijnlijk als gevolg van vertraagde mineralisatie van organisch gebonden $\mathrm{P}$ in combinatie met de gekozen meetmethode. De auteurs concluderen dat een verhoging van $\mathrm{P}$ wel te verwachten is bij intensief uitloopgebruik. 
Tabel 7

$\mathrm{N}$ - en P-gehaltes in bodemmonsters uit de uitloop van een groot en een klein koppel leghennen (Zorn et al., 2004).

\begin{tabular}{|c|c|c|c|c|c|c|c|c|}
\hline \multirow[b]{3}{*}{ Diepte $\mathrm{cm} \backslash$ jaar } & \multicolumn{4}{|c|}{ Koppel 750 hennen } & \multicolumn{4}{|c|}{ Koppel 7.000 hennen } \\
\hline & \multicolumn{2}{|c|}{$\begin{array}{l}N_{\min } \text {-Gehalte } \\
\text { (kg N/ha) }\end{array}$} & \multicolumn{2}{|c|}{$\begin{array}{l}\text { PCAL-Gehalte } \\
\text { (mg P/100g) }\end{array}$} & \multicolumn{2}{|c|}{$\begin{array}{l}N_{\min } \text {-Gehalte } \\
\text { (kg N/ha) }\end{array}$} & \multicolumn{2}{|c|}{$\begin{array}{l}\text { PcAL-Gehalte } \\
\text { (mg P/100g) }\end{array}$} \\
\hline & 2002 & 2003 & 2002 & 2003 & 2002 & 2003 & 2002 & 2003 \\
\hline \multirow{2}{*}{\multicolumn{9}{|c|}{$\begin{array}{l}\text { Dichtbij stal } \\
<25 \mathrm{~m}\end{array}$}} \\
\hline & & & & & & & & \\
\hline $0-30$ & 147 & 358 & 3,5 & 3,5 & 95 & 191 & 5,3 & 16,7 \\
\hline $30-60$ & 59 & 134 & 0,9 & 1,3 & 45 & 52 & 0,9 & 4,4 \\
\hline $60-90$ & 41 & 64 & 0,9 & 1,3 & $*$ & $*$ & $*$ & $*$ \\
\hline $0-90$ & 247 & 556 & & & 140 & 243 & & \\
\hline \multicolumn{9}{|l|}{ Ver van stal } \\
\hline \multicolumn{9}{|l|}{$>25 \mathrm{~m}$} \\
\hline $0-30$ & 16 & 76 & 1,8 & 1,3 & 32 & 59 & 7,5 & 8,8 \\
\hline $30-60$ & 4 & 17 & 0,4 & 0,4 & 10 & 12 & 1,8 & 1,3 \\
\hline $60-90$ & 4 & 13 & 0,4 & $<0,4$ & $*$ & $*$ & $*$ & $*$ \\
\hline $0-90$ & 24 & 106 & & & 42 & 71 & & \\
\hline
\end{tabular}

*monstername op $90 \mathrm{~cm}$ diepte was niet mogelijk.

Aarnink et al. (2005) onderzochten de bemestingsdruk van de uitloop van een praktijkbedrijf met 3000 hennen en een proefstal met twee afdelingen van ca. 250 hennen. Ze bepaalden het aantal, de spreiding en de samenstelling van keutels per oppervlakte-eenheid. Uit dit onderzoek kwam naar voren, dat de mineralenbelasting over de eerste 20 meter vanaf de stal redelijk uniform verdeeld was en verder van de stal afnam. De stikstof- en fosforexcretie in de eerste 20 meter van de uitloop was voor de proeflocatie en de praktijklocatie redelijk vergelijkbaar (tabel 8). De K-belasting was op de proeflocatie hoger, waarschijnlijk als gevolg van een hoger $\mathrm{K}$-gehalte in het voer. De $\mathrm{N}$ en P-excretie in de eerste 20 meter vanaf de stal was erg hoog en overschreed de norm vanuit de wetgeving ruimschoots.

Uitgaande van een gemiddelde mestproductie per kip van $75 \mathrm{~kg} / \mathrm{jaar}$ (dit komt overeen met 205 g/dag; Handboek voor de Pluimveehouderij 2004), kon berekend worden hoeveel van de mest op de eerste 20 meter terecht gekomen was (tabel 7). Met minimaal $12,1 \%$ is dit al hoger dan het maximum wat in paragraaf 2.2.2 is aangegeven bij een gelijkmatige verspreiding over de uitloop $(10,9 \%)$. Doordat de meeste mest op de eerste $20 \mathrm{~m}$ van de stal terechtkomt is hier sprake van een sterke overbemesting met mineralen. Daar komt bij, dat op dit gedeelte van de uitloop ook vrijwel geen begroeiing was, waardoor in feite alle mineralen die worden toegevoegd onbenut blijven en kunnen uit- of afspoelen of zich ophopen in de bodem.

Tabel 8

Berekende gemiddelde mest- en mineralenbelasting van de eerste $20 \mathrm{~m}$ van de uitloop (gemeten vanaf de stal) voor de verschillende stallen, omgerekend naar $\mathrm{kg}$ per hectare per jaar (Aarnink et al., 2005).

\begin{tabular}{|c|c|c|c|c|c|}
\hline & \multicolumn{2}{|c|}{$\begin{array}{l}\text { Hoeveelheid geproduceerde } \\
\text { mest in de eerste } 20 \mathrm{~m} \text { van de } \\
\text { uitloop (per dag per kip) }\end{array}$} & \multicolumn{3}{|c|}{$\begin{array}{l}\text { Mineralenbelasting van de eerste } 20 \mathrm{~m} \\
\text { van de uitloop, } \mathrm{kg} / \text { (jaar.ha) }\end{array}$} \\
\hline & Gram & $\begin{array}{l}\% \text { van totale } \\
\text { mestproductie }\end{array}$ & $\mathbf{N}$ & $\mathrm{P}\left(\mathrm{P}_{2} \mathrm{O}_{5}\right)$ & K \\
\hline Praktijklocatie & 55 & 26,5 & 2845 & $709(1716)$ & 1074 \\
\hline Proeflocatie (scharrel) & 25 & 19,4 & 2637 & $597(1367)$ & 1562 \\
\hline Proeflocatie (volière ) & 40 & 12,1 & 2412 & $552(1264)$ & 1530 \\
\hline
\end{tabular}



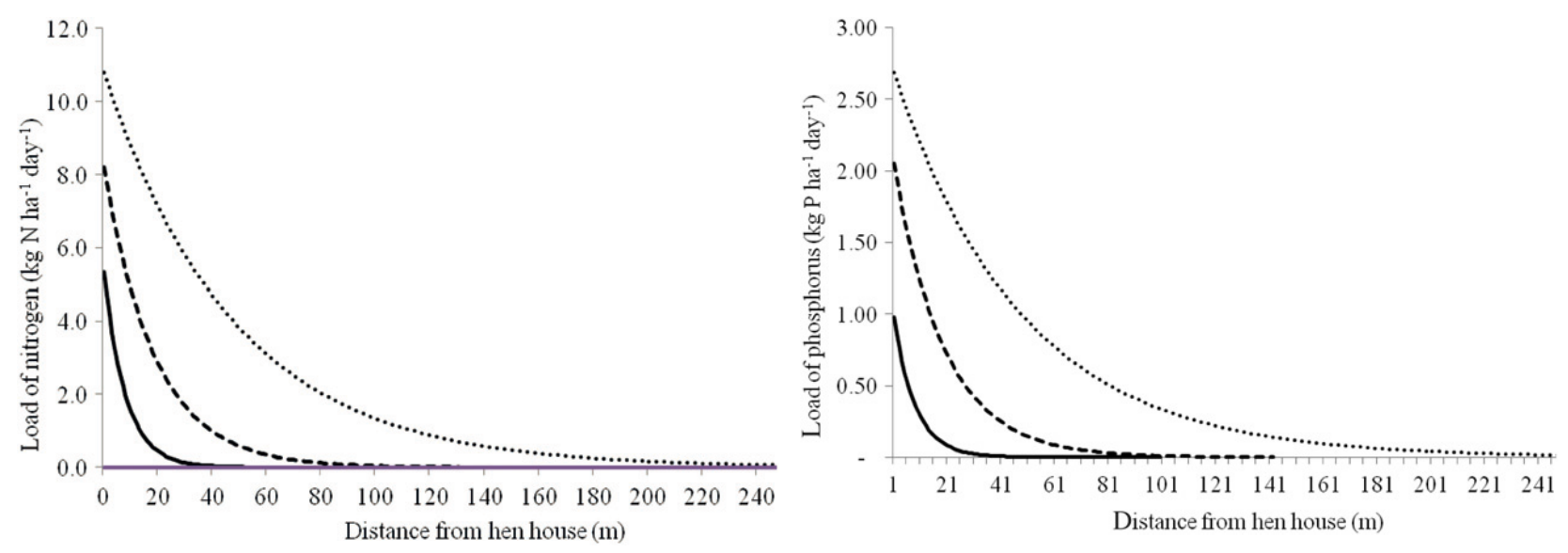

Figur 1a en $1 b \quad$ Relatie tussen $N$ en $P$ belasting van de uitloop en de afstand naar de stal (Dekker et al., 2012). De 3 verschillende lijnen geven 3 bedrijven weer.

Dekker et al. (2010; 2012) onderzochten drie biologische legbedrijven met volièrehuisvesting om te zien of de totale stikstof- en fosforexcretie per hen in de uitloop verschilde tussen de drie meetbedrijven. Een tweede doel was vast te stellen of er verschil in mestbelasting was tussen de zones van 0 tot 10 meter, 10 tot 25 meter en 25 meter en verder van de stal, binnen en tussen de drie meetbedrijven. Daarbij werd gemeten hoeveel dieren er gebruik maakten van de uitloop en hoe ver ze van de stal gingen. In een aantal vastgestelde zones in de uitloop werden de mestkeutels verzameld en bemonsterd. Opvallend was dat op twee van de drie bedrijven de hennen of dicht bij de stal of juist wat verderop verbleven en bij het derde bedrijf vooral dicht bij de stal.

De drie bedrijven verschilden in mate van inrichting van de uitloop. Het bedrijf met de rijkste inrichting had het hoogste gebruik van de uitloop, hetgeen overeen komt met bevindingen uit andere onderzoeken (tabel 2). Er was een sterke relatie tussen het gebruik van de uitloop en de stikstof en fosforbelasting ervan: $4 \%$ tot $26 \%$ van de totale stikstofexcretie en van $4 \%$ tot $27 \%$ van de totale fosforexcretie kwam in de uitloop (tabel 9). De stikstof- en fosforbelasting overschreed in bijna alle zones op alle meetbedrijven de bemestingsnorm. De stikstof- en fosforbelasting in de zone van 0 tot $10 \mathrm{~m}$ van de stal was dermate hoog (tabel 10), dat de auteurs concludeerden dat maatregelen op alle meetbedrijven noodzakelijk zijn.

\section{Tabel 9}

Fosfor (tussen haakjes fosfaat) en stikstof excretie in de uitloop op 3 biologische bedrijven met verschillend ingerichte uitlopen, uitgedrukt in gram per hen per jaar en in percentage van de totale excretie op het bedrijf (Dekker et al., 2010).

\begin{tabular}{|c|c|c|c|c|c|c|}
\hline \multirow{2}{*}{$\begin{array}{l}\text { Mate van } \\
\text { beschutting }\end{array}$} & \multicolumn{2}{|l|}{ Fosfor } & \multicolumn{2}{|l|}{ Stikstof } & \multirow{2}{*}{$\begin{array}{l}\text { in zone 0- } \\
10 \mathrm{~m} \\
\%\end{array}$} & \multirow{2}{*}{$\begin{array}{l}\text { in zone > } \\
25 \mathrm{~m} \\
\%\end{array}$} \\
\hline & $\begin{array}{l}\text { g/ jaar per } \\
\text { hen }\left(\mathrm{P}_{2} \mathrm{O}_{5}\right)\end{array}$ & $\begin{array}{l}\% \text { van totale } \\
\text { excretie }\end{array}$ & $\begin{array}{l}\text { g/ jaar per } \\
\text { hen }\end{array}$ & $\begin{array}{l}\% \text { van totale } \\
\text { excretie }\end{array}$ & & \\
\hline Veel & $43(98)$ & 19 & 177 & 18 & 45 & 40 \\
\hline Gemiddeld & 52 (119) & 27 & 213 & 26 & 41 & 44 \\
\hline Weinig & $6(14)$ & 4 & 36 & 4 & 64 & 0 \\
\hline
\end{tabular}

Voor deze rapportage toegevoegd $\mathrm{P}_{2} \mathrm{O}_{5}$ berekend als 2,29 $\mathrm{P}$. 
Tabel 10

Fosfor (tussen haakjes fosfaat) en stikstof excretie in de eerste 10 meter van de uitloop op 3 biologische bedrijven met verschillend ingerichte uitlopen, uitgedrukt in $\mathrm{kg}$ per hectare per jaar (Dekker et al., 2010).

\begin{tabular}{lll} 
Inrichting uitloop & Fosfor in zone 0-10 $\mathrm{m}\left(\mathrm{P}_{2} \mathrm{O}_{5}\right)$ & Stikstof in zone 0-10 $\mathrm{m}$ \\
& $\mathrm{kg} / \mathrm{ha} /$ jaar & $\mathrm{kg} / \mathrm{ha} /$ jaar \\
\hline Rijk ingericht & $1676(3838)$ & 6900 \\
\hline Ingericht & $2259(5173)$ & 9297 \\
\hline Zeer open & $1938(4438)$ & 3861 \\
\hline
\end{tabular}

Voor deze rapportage toegevoegd $\mathrm{P}_{2} \mathrm{O}_{5}$ berekend als 2,29 $\mathrm{P}$.

Van der Burgt en Bestman (2009) onderzochten bodemmonsters uit de uitlopen van vier biologische legbedrijven in de periode 2006-2008. Omdat metingen aan stikstof, organische stof, kalium en pH direct beïnvloed worden door weersomstandigheden en bodemleven en dit bij fosfaatmetingen veel minder het geval is, was de verwachting dat er een duidelijke relatie zou bestaan met de aan- en afvoer van fosfor.

De auteurs hebben zich daarom voor fosfaat gericht op drie vragen:

- Zijn er grote afwijkingen tussen P-totaal (de totale voorraad fosfor in de grond) en P-Al (deel van de totale fosfor voorraad dat voor plantengroei beschikbaar is)?

- Is de fosforlast nabij de stal hoger dan verder weg?

- Neemt het fosfaatgehalte van de grond toe gedurende twee jaar?

Er bleek een goed verband te bestaan tussen P-totaal en P-Al, waaruit de auteurs concludeerde dat er geen sprake was van bodemprocessen die fosfor vastlegden, waardoor het niet meer beschikbaar zou zijn voor plantengroei. Een eventueel structureel verlies van een vast deel van fosfor door b.v. uitspoeling is hierbij niet in overweging genomen.

Gemiddeld over de vier bedrijven was een afname te zien van de P-Al naarmate de afstand naar de stal groter was, hetgeen overeen kwam met de benutting van de uitloop door de kippen (minder kippen ver van de stal af). De auteurs vonden geen toename in P-Al over de tijd. Er werd geen accumulatie van fosfor geconstateerd, hetgeen in tegenspraak is met de bevindingen van Aarnink et al. (2005) en Dekker et al. (2012). De auteurs geven hiervoor als verklaring dat de aanvoer van fosfor naar de uitloop lager zou kunnen zijn dan berekend. Dit zou kunnen worden veroorzaakt door transport van de grond vanuit de uitloop de stal in, doordat dit aan de poten van de hennen blijft hangen of doordat dit opgegeten wordt door de kippen en in de stal uitgescheiden wordt. Deze aanname werd versterkt door de ervaring van een van de deelnemende bedrijven, waarbij mest uit de stal werd verbrand. Deze mest bleek bij analyse herhaaldelijk een aanzienlijk hogere zandfractie te bevatten dan mest uit andere, intensieve kippenhouderijen zonder uitloop (mondelinge mededeling van betreffende deelnemer). Om te controleren of fosfor inderdaad op deze manier afgevoerd wordt, dient nader onderzoek plaats te vinden.

Op een van de bedrijven zijn metingen gedaan aan nitraat in bodemmonsters uit de uitloop $(0-30 \mathrm{~cm}$ diep) op verschillende afstanden van de stal en over een periode van anderhalf jaar. Hieruit kwam naar voren dat metingen dichtbij de stal bijna altijd een hoger nitraatgehalte laten zien dan metingen verder van de stal af. Ook bleek er een toename te zijn in nitraatgehalte in de metingen die het laatst genomen waren. De auteurs geven echter aan dat er teveel factoren in het spel zijn om een sluitende conclusie over de stikstofdynamiek op te stellen (Burgt and Bestman, 2009).

Vast staat, dat in de zone nabij de stal geen opname van stikstof plaatsvindt door planten, dus daar zal minerale stikstof in de bodem voor een deel nitrificeren en denitrificeren en voor een deel uitspoelen. 


\section{Conclusies}

Uit de onderzoeks- en demonstratieprojecten die in Nederland en elders in Europa zijn uitgevoerd, is ruim informatie beschikbaar over de mineralenbelasting in de uitloop (tabel 11). Enerzijds wijst de informatie er op, dat zonder maatregelen de mineralenbelasting met onder andere $\mathrm{N}$ en $\mathrm{P}$ in de kippenuitloop vele malen hoger is of kan zijn dan op normale, begroeide en conform de wettelijke normen bemeste akkers.

De effecten van de overbemesting van een uitloop op het milieu, zoals uitspoeling, afspoeling en gasvormige $\mathrm{N}$ emissies zijn maar zeer beperkt beschreven. Voor landbouwgrond is dit wel bekend, maar het is de vraag of de situatie van een uitloop vergeleken kan worden met die van reguliere landbouwgrond.

\section{Tabel 11}

Overzicht bevindingen $N$ - en P-belasting uitloop.

\begin{tabular}{|c|c|c|c|c|}
\hline \multirow[t]{2}{*}{ Onderzoek } & N & & Fosfaat & Fosfaat \\
\hline & belasting uitloop & opmerkingen & belasting uitloop & opmerkingen \\
\hline Zorn et al. (2004) & $\begin{array}{l}74 \text { kg/ } 100 \\
\text { hennen/jr }\end{array}$ & $\begin{array}{l}\text { lekt naar } \\
\text { grondwater; dichter } \\
\text { bij stal meer nitraat }\end{array}$ & $\begin{array}{l}18 \mathrm{~kg} \mathrm{P}=41 \mathrm{~kg} \\
\mathrm{P}_{2} \mathrm{O}_{5} / 100 \\
\text { hennen } / \mathrm{jr}\end{array}$ & $\begin{array}{l}\text { lekt naar } \\
\text { oppervlaktewater; tot } \\
25 \mathrm{~m} \text { conc per } 100 \mathrm{gr} \\
\text { neemt toe, verder weg } \\
(25-50 \mathrm{~m}) \text { concentratie } \\
\text { gelijk of neemt iets af }\end{array}$ \\
\hline $\begin{array}{l}\text { Aarnink et al. } \\
\text { (2006) }\end{array}$ & $\begin{array}{l}\text { 1e } 20 \mathrm{~m}: 2412- \\
2845 \mathrm{~kg} / \mathrm{ha} \text { per } \\
\text { jaar }\end{array}$ & $\begin{array}{l}\text { min. } 12 \% \text { mest op } \\
\text { de } 1 \text { e } 20 \mathrm{~m} \text {, hetgeen } \\
\text { ver boven de norm } \\
\text { is }\end{array}$ & $\begin{array}{l}\text { 1e } 20 \mathrm{~m}: 552-709 \\
\mathrm{~kg} \mathrm{P}=1264-1624 \\
\mathrm{~kg} \mathrm{P}_{2} \mathrm{O}_{5} \mathrm{~kg} \text { fosfaat } \\
\text { /ha per jaar }\end{array}$ & $\begin{array}{l}\text { min. } 12 \% \text { mest op de } \\
1 \text { e } 20 \mathrm{~m} \text {, hetgeen ver } \\
\text { boven de norm is }\end{array}$ \\
\hline $\begin{array}{l}\text { Dekker et al. } \\
(2010 ; 2012)\end{array}$ & $\begin{array}{l}\text { 0-10m van de stal: } \\
6686 \mathrm{~kg} / \mathrm{ha} \text { per } \\
\text { jaar }\end{array}$ & $\begin{array}{l}\text { gemiddelde van } \\
\text { metingen op } 3 \\
\text { biologische } \\
\text { bedrijven }\end{array}$ & $\begin{array}{l}\text { 0-10m van de stal: } \\
1958 \mathrm{~kg} P=4484 \\
\mathrm{~kg} \mathrm{P}_{2} \mathrm{O}_{5} / \text { ha per jaar }\end{array}$ & $\begin{array}{l}\text { gemiddelde van } \\
\text { metingen op } 3 \\
\text { biologische bedrijven }\end{array}$ \\
\hline Zeelen (1995) & 475 kg/ha/jaar & & $\begin{array}{l}307 \mathrm{~kg} \\
\mathrm{P}_{2} \mathrm{O}_{5} / \mathrm{ha} / \mathrm{jaar}\end{array}$ & \\
\hline
\end{tabular}

\subsection{Emissies in de buitenuitloop}

Volgens Lippmann (2011) wordt de emissie van ammoniak uit de bodem beïnvloed door:

- het klimaat: bij droog en warm weer emitteert een oppervlak meer ammoniak dan bij nat en koel weer

- bodemvochtigheid: deze heeft een geringe invloed, bij droge bodem is er minder emissie.

- luchtsnelheid: bij hogere snelheden meer emissie

- begroeiing: bij een onbegroeid oppervlak lager dan bij grasland

Uit metingen van Lippmann (2011) kwam naar voren, dat bacteriën in de stallucht en afvoerlucht van pluimveestallen in concentraties van $10^{6}-10^{7} \mathrm{kve}$ (kolonievormende eenheden) per $\mathrm{m}^{3}$ lucht optraden. Dit komt overeen met de maximale concentraties, die hij in de literatuur gevonden had voor pluimveebedrijven. Schimmels en gisten kwamen in lagere concentraties voor $\left(10^{2}-10^{4} \mathrm{kvem}^{3}\right)$. Deze bevinding komen goed overeen met de bevindingen uit de literatuur.

De concentratie van bacteriën in de stallucht en de uitlaatlucht kwamen overeen met de concentratie deeltjes kleiner dan 2,5 micron. Hieruit kan worden afgeleid dat bij hoge fijnstofconcentraties (PM 2,5) verhoogde uitstoot van bacteriën met de ventilatielucht is te verwachten. Voor schimmels gold dit niet, omdat deze zich anders gedragen dan fijnstofdeeltjes.

Lippmann (2011) gaf aan dat concentratie in de stallucht duidelijk hoger is dan wat in de uitgeblazen ventilatielucht uit de stal gemeten wordt. De concentraties in de buitenlucht zullen een combinatie zijn van depositie vanuit de stal en emissie vanaf de uitloop. Onderscheid hierin is echter niet gemaakt. 


\subsubsection{Ammoniakemissie in de uitloop}

Aarnink et al. (2005) onderzochten de ammoniakemissie vanaf de uitloop. Ze gebruikten daarvoor een speciaal ontwikkelde meetdoos, die over een vooraf geselecteerd oppervlak van de uitloop geplaatst werd en waardoor een gestandaardiseerde hoeveelheid lucht geblazen werd. De ingaande en uitgaande lucht van de meetdoos werd bemonsterd voor $\mathrm{NH}_{3}$. De variatie tussen de metingen bleek erg groot en soms werd zelfs een negatieve emissie gemeten. Deze lagen echter wel binnen de range van de variatie. Bij alle stallen nam de ammoniakemissie af bij toenemende afstand tot de stal (figuur 2 ), hetgeen te verwachten was op basis van het gebruik van de uitloop door de kippen. Bij een hogere temperatuur en luchtvochtigheid nam de emissie toe. In tabel 12 staan de gemiddelde emissies die berekend werden met behulp van de berekende regressielijnen (waarvan er 1 in figuur 2 gegeven is).

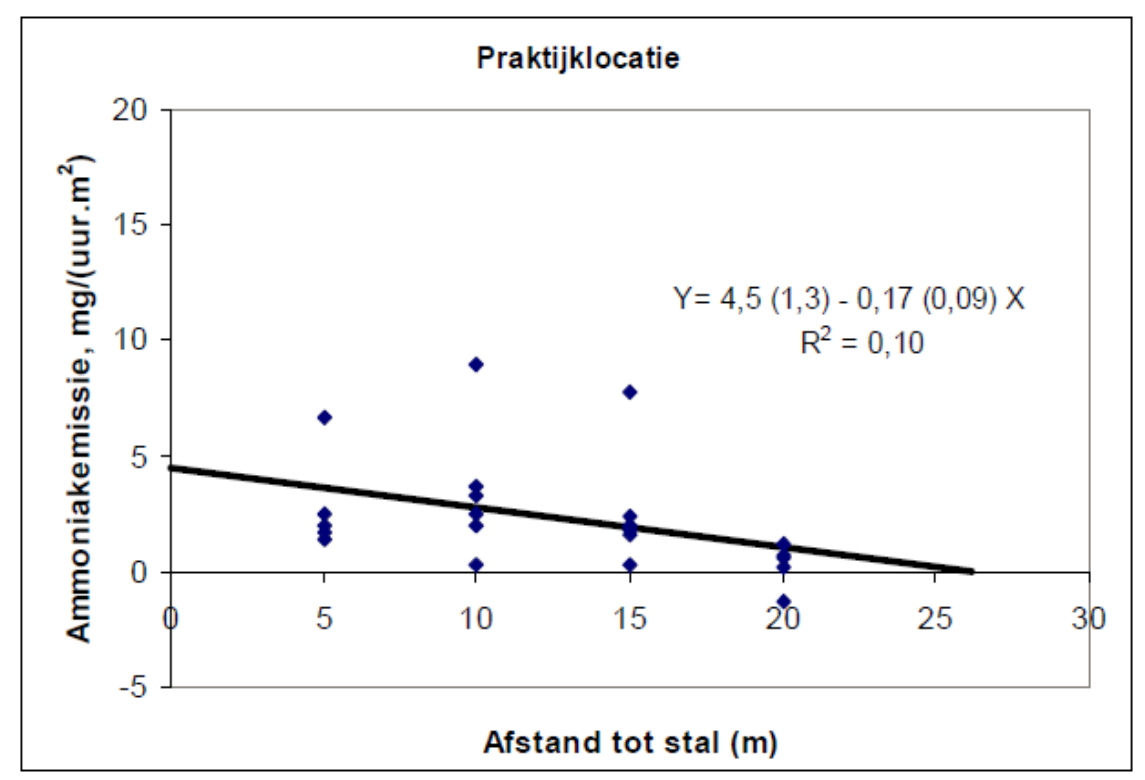

Figuur 2 Relatie tussen afstand tot de stal en de ammoniakemissie vanaf een onverharde uitloop voor leghennen op een praktijklocatie met 3000 leghennen. De regressielijn is in de figuur aangegeven, met tussen haakjes de standaardfout (Aarnink et al., 2005).

Tabel 12

Berekende emissies van de uitloop per meetlocatie (Aarnink et al., 2005).

\begin{tabular}{|c|c|c|c|c|c|}
\hline & \multicolumn{3}{|l|}{ Emissie } & \multirow{2}{*}{$\begin{array}{l}\text { Emissie- } \\
\text { factor stal } \\
\text { (g/jaar/kip) }\end{array}$} & \multirow{2}{*}{$\begin{array}{l}\% \text { emissie } \\
\text { vanuit de } \\
\text { uitloop t.o.v. } \\
\text { stal }\end{array}$} \\
\hline & (g/uur) & (mg/uur/kip) & (g/kip/jaar) & & \\
\hline Praktijklocatie & 6,0 & 2,0 & 17,5 & 315 & 5,5 \\
\hline Proeflocatie (scharrel) & 0,21 & 0,95 & 8,3 & 315 & 2,6 \\
\hline Proeflocatie (volière ) & 0,31 & 0,86 & 7,6 & 90 & 8,4 \\
\hline
\end{tabular}

De auteurs concluderen dat de gemeten ammoniakemissie vanaf de uitloop relatief gering is ten opzichte van de emissie uit de stal, maar niet verwaarloosbaar. Meerdere metingen, verspreid over het jaar en met verschillende luchtsnelheden over het emitterend oppervlak, zijn nodig om een nauwkeuriger beeld te krijgen van de emissie vanaf de uitloop. Metingen op grotere afstanden tot de stal dan 20 m zullen daarnaast moeten bevestigen of de emissie daar inderdaad verwaarloosbaar is. De oriënterende metingen, zoals gedaan in het onderzoek van Aarnink et al. (2005), geven echter een duidelijke richting aan, waaruit blijkt dat ammoniakemissie vanaf de uitloop geen grote bijdrage geeft aan de emissies in de legpluimveehouderij. 


\subsubsection{Geur- en fijnstofemmisie in de uitloop}

Er zijn geen metingen bekend van geur-, methaan- en fijnstofemissies uit de uitloop. Metingen aan fijnstof zijn vooral uitgevoerd in de dierruimten. Ook onderzoek naar maatregelen ter reductie van fijnstof richten zich vooral op de binnenruimte (De Buisonjé et al., 2009).

Lippmann (2011) heeft geurconcentratie (geureenheden) gemeten in de stallucht, in de uitgaande ventilatielucht en in de buitenlucht (tabel 13). De gemiddelde referentiewaarden van de buitenlucht waren 19 GE. Deze metingen aan de buitenlucht betreffen zowel de depositie uit de stal als mogelijke emissie vanuit de uitloop. Onderscheid werd daar niet in gemaakt.

\section{Tabel 13}

Geurmeting (Geureenheden, GE/m³) op legbedrijf (Lippmann, 2011).

\begin{tabular}{|c|c|c|c|c|c|}
\hline \multirow[t]{2}{*}{ Jaargetijde } & \multirow[t]{2}{*}{ Metingnr. } & \multirow[t]{2}{*}{ Stallucht } & \multicolumn{2}{|l|}{ Ventilatielucht } & \multirow[t]{2}{*}{ Buitenlucht } \\
\hline & & & koker onderin & koker bovenin & \\
\hline \multirow[t]{2}{*}{ Voorjaar } & 1 & 30 & 36 & 25 & 19 \\
\hline & 2 & 27 & 16 & 38 & 15 \\
\hline \multirow[t]{2}{*}{ Zomer } & 1 & 108 & 110 & 80 & 34 \\
\hline & 2 & 50 & 50 & 60 & 18 \\
\hline \multirow[t]{2}{*}{ Herfst } & 1 & 180 & 210 & 180 & 18 \\
\hline & 2 & 38 & 34 & 50 & 10 \\
\hline \multirow[t]{3}{*}{ Winter } & 1 & 71 & 53 & 57 & 24 \\
\hline & 2 & 38 & 32 & 63 & 7 \\
\hline & 3 & 38 & 24 & 27 & 21 \\
\hline
\end{tabular}

\subsubsection{Methaan en lachgas}

Over de uitstoot van methaan $\left(\mathrm{CH}_{4}\right)$ en lachgas $\left(\mathrm{N}_{2} \mathrm{O}\right)$ uit de uitloop van leghennen is nagenoeg niets bekend. Er zijn wel enkele gegevens bekend voor vleeskuikens. Meda et al. (2012) hebben in de uitloop bij een biologische vleeskuikenstal gemeten. Ze hebben geen emissie voor ammoniak gemeten, maar wel $\mathrm{N}_{2} \mathrm{O}$ en $\mathrm{CH}_{4}$.

Voor $\mathrm{N}_{2} \mathrm{O}$ wordt een emissie geschat van 2,71 tot $4,76 \mathrm{~kg} \mathrm{~N} \mathrm{~N}_{2} \mathrm{O}-\mathrm{N}$ per ha per jaar. Uitgaande van $4 \mathrm{~m}^{2}$ per dier is de emissie per jaar per dier dan 1,084 - 1,904 gr. Er zijn geen emissies gegeven vanuit de stal. De emissie uit stallen voor regulier gehouden vleeskuikens in Nederland is volgens Mosquera en $\mathrm{Hol}$ (2012) $10 \mathrm{gr} \mathrm{N}$ O per dierplaats per jaar.

Voor $\mathrm{CH}_{4}$ berekenen Meda et al (2012) op basis van de geschatte mestproductie in de uitloop een emissie van 0,03 kg per ha per jaar. Hierbij is echter geen rekening gehouden met de opname van $\mathrm{CH}_{4}$ door micro-organismen in de grond. Deze opname wordt geschat op $0,5 \mathrm{~kg} \mathrm{CH}-\mathrm{C}$ per ha per jaar bij grasland. Netto zou er dan een afname van de $\mathrm{CH}_{4}$ emissie zijn. De auteurs geven echter ook aan dat er veel onzekerheden zijn bij de genoemde waarden.

Waarschijnlijk zullen de waardes voor de uitloop van leghennen niet veel anders liggen dan voor de uitloop van vleeskuikens.

\subsection{Vergelijking milieueffecten uitloop leghennen met vroegere eendenhouderij}

Traditioneel was de eendensector geconcentreerd rond Harderwijk en Ermelo. Sinds 1991 vielen eenden onder de Mestwetgeving en per 1998 moesten de eendenhouders aan de nieuwe normen voor fosfaatbemesting voldoen. Dit betekende dat vleeseenden alleen nog in stallen gehuisvest konden worden. Informatie over de Nederlandse houderij van eenden in uitloop is daardoor oud. Na het van kracht worden van de verplichting om eenden binnen te houden is veel onderzoek aan de milieuaspecten gedaan. Er zijn geen milieuonderzoeken bekend uit de periode dat de eenden buiten liepen. 
Uit een rapport van Zimmerman et al. (1990) zijn de volgende gegevens gehaald over de Nederlandse eendenhouderij:

Omdat de Barbarie-eend onder Nederlandse omstandigheden moeilijk te houden was, werd met name de Pekingeend gehouden, vooral van het Engelse merk "Cherry Valley". Op de mestbedrijven werden eendagseenden eerst enkele weken in een opfokstal gehouden. Deze stallen hadden soms een gedeeltelijk rooster (geplastificeerd gaas), maar meestal waren ze ingericht met een volledig roostervloer. Na de opfokperiode gingen de eenden naar buiten. Dit buiten afmesten kon van maart tot en met november. Per hectare werden zo'n 2000 eenden per ronde gehouden. Voer werd meestal via voederbakken verstrekt. Water werd via vlotterbakken en drinkgoten verstrekt.

Het eindgewicht van de dieren kon variëren al naar gelang het seizoen, het type dier of het bedrijfssysteem (zwaar / licht mesten). Gemiddeld werd een eindgewicht van 2,5 kg bereikt in circa 8 weken.

Omdat er geen gestructureerde centrale administratie was, waren geen goede productiecijfers beschikbaar. Om toch een kostprijsberekening te kunnen uitvoeren, zijn Zimmerman et al. (1990) van een aantal uitgangspunten uitgegaan (tabel 14). Deze zullen de waarheid redelijk benaderen en geven een goede indruk van de eendenhouderij eind jaren 90. In 1989 waren er volgens Zimmerman et al. (1990) 66 eendenmesterijen, waarvan 61 in de provincie Gelderland, voornamelijk in de omgeving van Harderwijk en Ermelo. In 1990 hielden 18 bedrijven de eenden binnen, de overige bedrijven mestten hun eenden buiten af. In 1988 werd driekwart van de totale Nederlandse tamme eendenstapel gehouden op 21 bedrijven met een omvang van tenminste 10.000 slachteenden. Slechts $8 \%$ van de slachteenden wordt gehouden op bedrijven met een omvang van minder dan 5.000 eenden.

Tabel 14

Uitgangspunten Nederlandse eendenhouderij in 1990 bij afmesten in een stal of buiten (Zimmerman et al., 1990).

\begin{tabular}{lll} 
& Binnen & Buiten \\
Periode & jaarrond & maart-november \\
\hline Eindgewicht $(\mathrm{kg})$ & 2,5 & 2,5 \\
\hline Voerconversie & 2,8 & 2,9 \\
\hline Uitval (\%) & 3 & 4 \\
\hline Mestperiode (dagen) & 49 & 49 \\
\hline Bezetting opfokstal (dieren $\left./ \mathrm{m}^{2}\right)$ & 15 & 15 \\
\hline Bezetting afmestperiode $\left(\right.$ dieren $\left./ \mathrm{m}^{2}\right)$ & 7,5 & 0,2 \\
\hline Rondes per jaar* & 17 & 13 \\
\hline
\end{tabular}

*uitgaande van een meerleeftijdensysteem waarbij de eenden in 7 weken in 3 verschillende stallen gehouden worden.

De systemen van eendenhouderij, met ofwel volledige binnenhouderij ofwel de eerste weken volledig binnen en dan volledig buiten, zijn niet te vergelijken met de houderij van leghennen met uitloop. Bij de eenden kwam gedurende $75 \%$ van het jaar alle mest van 2000 eenden per ha ( $5 \mathrm{~m}^{2} /$ eend) op de grond. De mestconcentratie zal rond voer- en waterbakken het hoogst geweest zijn en verder over het hele oppervlak gespreid zijn. Bij de legbedrijven komt 5-30\% van de hennen jaarrond gedurende ca $30 \%$ van de dag in de uitloop, waarbij de hennen vooral de eerste paar meter gebruiken.

Verder is de mest van eenden qua samenstelling en drogestof gehalte ook niet te vergelijken met die van leghennen (tabel 15 en 16). Dit zal ook zeker een effect hebben op uitwisseling naar de bodem en lucht. Als inderdaad $75 \%$ van het jaar gemiddeld 2000 eenden/ha buiten gehouden worden en er wordt gerekend met een jaarlijkse mineralen uitscheiding per eend, vergelijkbaar met vleeskuikens, dan is de belasting per ha $0.75 \times 2000 \times 0.52 \mathrm{~kg}=780 \mathrm{~kg} \mathrm{~N}$ en idem $\times 0.18=270 \mathrm{~kg} \mathrm{P}_{2} \mathrm{O}_{5}$. Deze berekende mineralenbelasting van de eendenuitlopen is lager dan die van leghennenuitlopen dicht bij de stal, maar overschrijdt de bemestingsnormen voor zowel stikstof als fosfaat aanzienlijk. 
Tabel 15

Gemiddelde samenstelling van vaste eendenmest ( $k g$ per ton) (Den Boer et al., 2012).

\begin{tabular}{|c|c|c|c|c|c|c|c|c|c|c|}
\hline Analyse & n & ds & os & $\mathbf{N}_{\text {tot }}$ & $\mathbf{N}_{\min }$ & Norg & $\mathrm{P}_{2} \mathrm{O}_{5}$ & $\mathrm{~K}_{2} \mathrm{O}$ & MgO & $\mathrm{Na}_{2} \mathrm{O}$ \\
\hline 1998 & 23 & 265 & 209 & 8,3 & 1,7 & 6,6 & 7,4 & 11,3 & 1,6 & 0,8 \\
\hline Sd & & 58 & 41 & 1,8 & 0,5 & -- & 2,3 & 2,7 & 0,7 & 0,3 \\
\hline 2011 & $5-226 *$ & 319 & 268 & 10,6 & 1,9 & 9,9 & 10,3 & 9,9 & 4,3 & 1,8 \\
\hline Mediaan & & 275 & 237 & 8,9 & 1,8 & 8,2 & 7,3 & 8,4 & 3,4 & 1,3 \\
\hline $\mathrm{Sd}$ & & 142 & 132 & 6,0 & 0,6 & 5,9 & 8,2 & 5,1 & 2,4 & 0,9 \\
\hline
\end{tabular}

* 5 voor $\mathrm{N}_{\text {min }}$ en $\mathrm{N}_{\text {org }}, 6$ voor organische stof, $\mathrm{MgO}$ en $\mathrm{Na}_{2} \mathrm{O}, 124$ voor $\mathrm{K}_{2} \mathrm{O}$ en 226 voor drogestof, $\mathrm{N}_{\text {tot }}$ en fosfaat.

\section{Tabel 16}

Vergelijking mediane samenstelling van organische meststoffen in $\mathrm{kg}$ per $1000 \mathrm{~kg}$ product, dichtheid in $\mathrm{kg}$ per $\mathrm{m}^{3}$ (Den Boer et al., 2012).

\begin{tabular}{|c|c|c|c|c|c|c|c|c|c|c|c|}
\hline Soort mest & Ds & $\begin{array}{l}\text { Org } \\
\text { stof }\end{array}$ & $\mathbf{N}_{\text {tot }}$ & $\mathbf{N}_{\min }$ & Norg & $\mathrm{P}_{2} \mathrm{O}_{5}$ & $\begin{array}{l}\mathbf{N}_{\min } / \\
\mathbf{N}_{\text {tot }} *\end{array}$ & $\begin{array}{l}\mathrm{N}_{\text {tot }} / \\
\mathrm{P}_{2} \mathrm{O}_{5} *\end{array}$ & K20 & MgO & $\mathrm{Na}_{2} \mathrm{O}$ \\
\hline \multicolumn{12}{|l|}{ Leghennen } \\
\hline -mestband & 573 & 416 & 25,6 & 2,5 & 23,1 & 19,6 & 0,10 & 1,31 & 15,5 & 5,5 & 1,7 \\
\hline $\begin{array}{l}\text {-mestband+ } \\
\text { nadroog }\end{array}$ & 810 & 427 & 34,1 & 3,9 & 30,2 & 27,8 & 0,11 & 1,23 & 20,1 & 5,9 & 2,3 \\
\hline $\begin{array}{l}\text {-strooisel } \\
\text { mest }\end{array}$ & 713 & 359 & 28,0 & 3,6 & 24,4 & 25,6 & 0,13 & 1,09 & 20,8 & 7,5 & 3,4 \\
\hline Eenden & 275 & 237 & 8,9 & 1,6 & 7,3 & 7,3 & 0,18 & 1,22 & 8,4 & 3,4 & 1,3 \\
\hline
\end{tabular}

*kg per $\mathrm{kg}$.

\subsection{Mogelijkheden ter reductie ongewenste effecten}

Er zijn diverse maatregelen mogelijk om ongewenste milieueffecten tegen te gaan. Ze kunnen gegroepeerd worden naar hun aanpak:

A. Lager mineralengehalte in de mest realiseren door aanpassing van het voer.

B. Gelijkmatigere verdeling van de mest over de uitloop.

C. Verzameling van mest in een apart deel van de uitloop en het van daaruit weghalen en afvoeren.

D. Maatregelen tegen uit- en afspoeling van mineralen.

E. Maatregelen om omzettingsprocessen tegen te gaan zodat geen of minder geur en ammoniak ontstaat, of geen andere $\mathrm{N}$-vormige emissie ontstaan.

\subsubsection{Lager mineralengehalte in de mest realiseren}

Minder fosfor en stikstof in het voer: door gebruik van fytase wordt de benutbaarheid van fosfor in het voer verhoogd, waardoor het fosforniveau in het voer verlaagd kan worden. Stikstofniveaus zouden verlaagd kunnen worden door verlaging van eiwitten in het voer. Hiermee moet echter goed rekening gehouden worden met voldoende beschikbaarheid van essentiële aminozuren.

Voor biologische bedrijven is er geen toegelaten fytase op de markt. Evenmin kunnen biologische bedrijven synthetische aminozuren toepassen om op verantwoorde wijze het eiwitgehalte van het voer te verlagen.

Al met al zullen de effecten van maatregelen in het voer op de mineralenconcentraties in de uitloop beperkt zijn.

\subsubsection{Gelijkmatigere verdeling van de mest over de uitloop}

Een gelijkmatige verdeling van de mest over de uitloop kan op meerdere manieren verkregen worden. 
Mobiele hokken: Allereerst is het gebruik van mobiele hokken een optie. Door deze regelmatig te verplaatsen, wordt de concentratie van mest rondom de stal niet opgelost, maar wordt wel een verspreiding van deze mest over de uitloop gerealiseerd. Deze optie is moeilijk te verwezenlijken voor koppels groter dan ca. 3000 hennen.

Egaler uitloopgebruik: Een andere optie is het stimuleren van de hennen om de gehele uitloop te gebruiken. Dit wordt bewerkstelligd door het aantrekkelijk maken van de uitloop:

- $\quad$ aanbrengen van natuurlijke beschutting (bomen struiken)

- aanbrengen van kunstmatige beschutting (afdakjes)

- $\quad$ stofbadmogelijkheden of water achterin de uitloop verstrekken.

- bomen met fruit of lekkere blaadjes achterin de uitloop kunnen helpen om de hennen naar achteren te lokken

- $\quad$ uitloop dichtbij de stal verharden, waardoor deze minder aantrekkelijk wordt en de hennen eerder verderop hun heil gaan zoeken.

- $\quad$ schapen en koeien in de uitloop: Bestman (2006) geeft aan dat deze dieren roofvogels verjagen, waardoor kippen zich veilig voelen in hun omgeving en met de koeien of schapen meegaan door de uitloop.

Een groot deel van de genoemde maatregelen zijn al of worden getest in de praktijk. De resultaten tonen aan dat het aantal hennen in de uitloop flink kan toenemen, maar dat het gebruik nog zeer ongelijkmatig blijft. Optimalisatie c.q. een strategischere inzet van de genoemde maatregelen is daarom noodzakelijk. De kans is echter groot dat geen van de maatregelen een substantiële bijdragen zal leveren aan een egalere verdeling. Ook zullen ze het gebruik dichtbij de stal niet wezenlijk reduceren, mogelijk zelfs stimuleren, zodat voor dat oppervlak zeker andere maatregelen nodig zijn.

Omweiden: door wisselbeweiding toe te passen zal een betere verspreiding van de mest gerealiseerd kunnen worden en kunnen mogelijk op de niet voor de hennen opengestelde delen via plantengroei en oogsten mineralen afgevoerd worden.

\subsubsection{Verzameling van mest in een apart deel en het van daaruit weghalen en afvoeren}

Omdat het merendeel van de mest rondom de stal valt, ligt het voor de hand voorzieningen voor het verwijderen van mest rondom de stal aan te leggen. Er worden hiertoe verschillende materialen rondom de stal gelegd:

- Verharding rond de stal. Dit kan een betonnen vloer zijn. Eventueel kan hierop een strooisellaag aangebracht worden.

- Afvoeren en opnieuw instrooien van de bovenste grondlaag: Burgt en Bestman (2009) noemen deze optie, waarbij niet aangegeven wordt wat ingestrooid moet worden. Een mengsel van zand en stro is in Duits onderzoek met succes gebruikt (Bestman, 2006). Om uitspoeling naar de bodem te voorkomen dient onder het strooisel een laag rubbermatten, kuildoek of gewoon beton aangebracht worden. Een voordeel is tevens dat de houtsnippers en de mest makkelijker te verwijderen zijn. Een kiezelbed gaat plasvorming tegen, maar het is vanuit milieuoogpunt wel nodig om met behulp van drainage het water op te vangen en naar een opslag te geleiden.

- Houtsnippers: Burgt en Bestman (2009) geven aan dat een laag van 15-20 cm houtsnippers rondom de stal de bodem droog houdt en de mineralen vasthoudt; wel moeten de houtsnippers elk jaar afgevoerd en vervangen worden. Elbe et al. (2005) hebben deze optie onderzocht en toonden een duidelijk lagere uitspoeling van stikstof aan (figuur 4).

- Mosselschelpen: Bestman (2006) rapporteert over stallen in Denemarken, waar mosselschelpen (gratis afval uit de visserij) rondom de stal aangebracht zijn. Soms wordt dit gemengd met stro gedaan. De schelpen worden in een laag van $20-70 \mathrm{~cm}$ aangebracht en worden jaarlijks vervangen. De schelpen verteren veel minder snel dan houtsnippers en zijn dus makkelijker af te voeren. Ze gaan plasvorming rondom de stal tegen, doordat het water erdoor zakt. Deels werken de schelpen ook om een betere verdeling van de mest over de uitloop te krijgen, omdat de hennen niet graag over de schelpen lopen en er dus niet lang opblijven staan. 
- Gefaseerde toegang tot uitloop: Elbe et al. (2005) geven als mogelijkheid aan om de hennen eerst gedurende 2 uur in de overdekte uitloop vast te houden alvorens ze toegang te geven tot de buitenuitloop. Hierdoor zal het merendeel van de mest in de overdekte uitloop komen en niet buiten. Ze geven verder geen cijfers, zodat dit wellicht nog niet uitgetest is. Deze maatregel zal alleen werken als de uitloop normaal gesproken direct bij het aangaan van het licht ter beschikking wordt gesteld. indien de uitloop later in de ochtend beschikbaar komt, is het de vraag hoe effectief deze maatregel zal zijn.

- Afvoer van (houtig) gewas uit de uitloop: met de afvoer van de gewassen, vooral als ze veel mineralen binden, worden mineralen afgevoerd uit de uitloop. Bestman (2006) geeft aan dat dit bijvoorbeeld met mais kan, maar dat dit wel afgevoerd moet worden om effect te hebben. Deze optie is goed uitvoerbaar in combinatie met wisselbeweiding, zodat de hennen altijd toegang hebben tot een uitloop met begroeiing en (nieuwe) beplanting de tijd kan krijgen om te herstellen of aan te slaan.

De gegeven maatregelen lijken in meer of mindere mate effectief. De eerder genoemde maatregelen om een betere verspreiding van de dieren over de uitloop te krijgen, werken echter het lokaal verzamelen van de mest tegen. Het ligt daarom voor de hand om een van beide oplossingsrichtingen te kiezen ofwel het verspreiden van de hennen op een zodanige wijze te regisseren, dat ze op een locatie komen, waar de mest goed af te voeren is.

\subsubsection{Maatregelen tegen uit- en afspoeling van mineralen}

Overkappen: Het overkappen van (een deel van) de uitloop is een goede mogelijkheid om uit- en afspoeling van mineralen tegen te gaan.

Drainage/afvoer regenwater: Burgt en Bestman (2009) noemen drainage, evt. gecombineerd met folie onder de grond als maatregel om te voorkomen dat mineralen in de bodem zakken. Het drainagewater dient dan wel opgevangen en afgevoerd te worden. Idealiter wordt het water eerst gezuiverd, bijvoorbeeld met behulp van een rietfilter. Uitspoeling van mineralen als gevolg van overmatig regenwater dient ook voorkomen te worden. Hiertoe kunnen dakgoten aan de stal bevestigd worden.

Bufferstrook langs waterlopen: Toepassen van een hek en een begroeide bufferstrook langs waterlopen, zodat de kippen niet in de nabijheid van een talud kunnen mesten en er geen mineralen kunnen afspoelen naar het oppervlaktewater.

Wisselbeweiding in combinatie met een groenbemester: (b.v. grasklaver). Burgt en Bestman (2009) geven van deze optie aan dat het weliswaar stikstof in de bodem brengt, maar geven ook aan dat hierdoor het gras beter zal gaan groeien en daardoor meer fosfaat zal opnemen. Gras moet dan wel geoogst en afgevoerd worden.

Gaas op gras: Elbe et al. (2005) hebben het afdekken van de grasmat met gaas onderzocht (figuren 3 en 4). De grasmat bleef goed intact, waardoor er minder uitspoeling van mineralen optrad. Burgt en Bestman (2009) geven aan dat dit wel een erg dure oplossing is (20-30 euro/ $\mathrm{m}^{2}$ in de proef).

Niet al deze maatregelen zullen even effectief zijn en van een aantal maatregelen zijn de kosten erg hoog. 


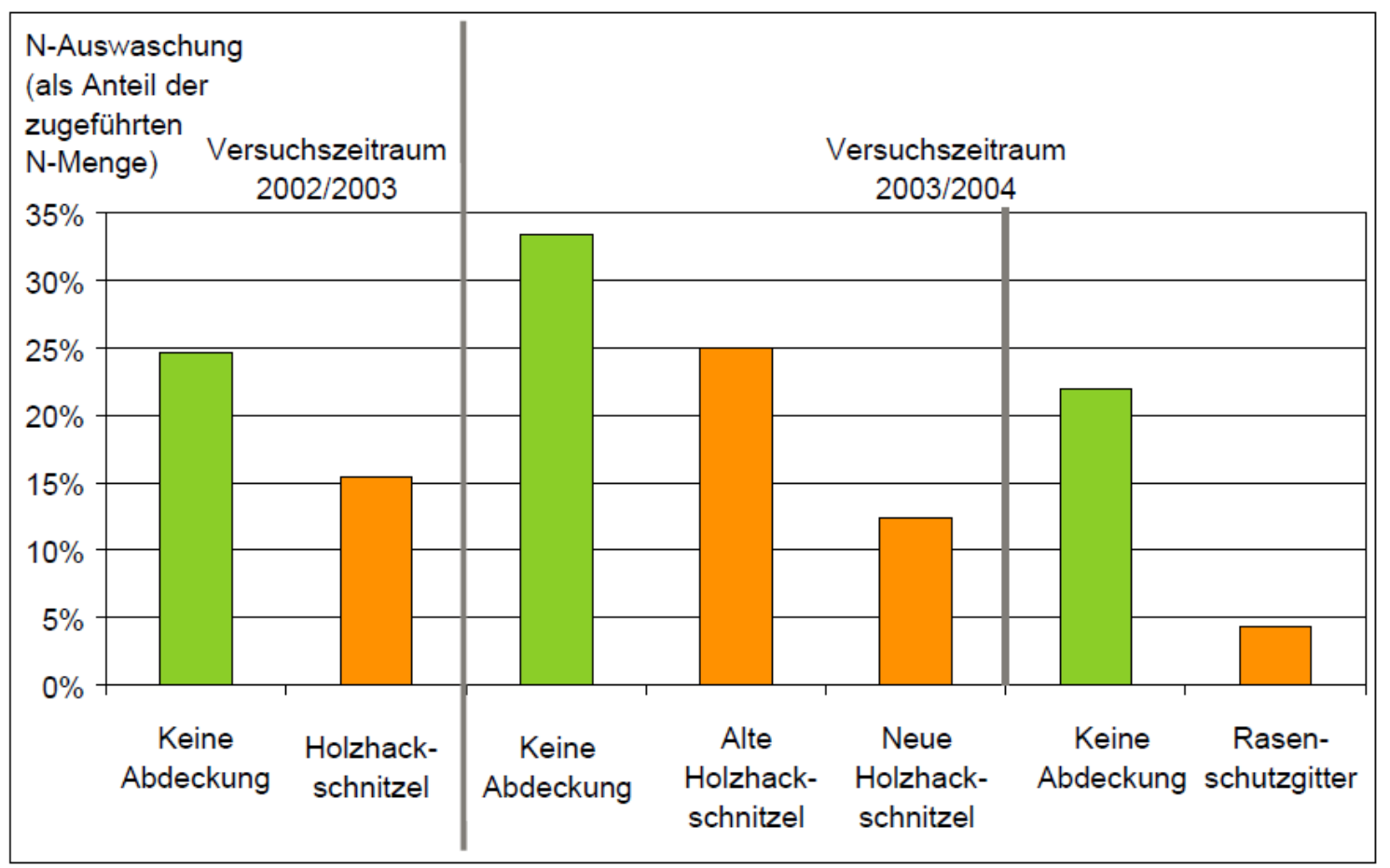

Figuur 3 Reduceren van N-uitspoeling door gebruik van verschillende afdekmaterialen (Elbe et al., 2005).

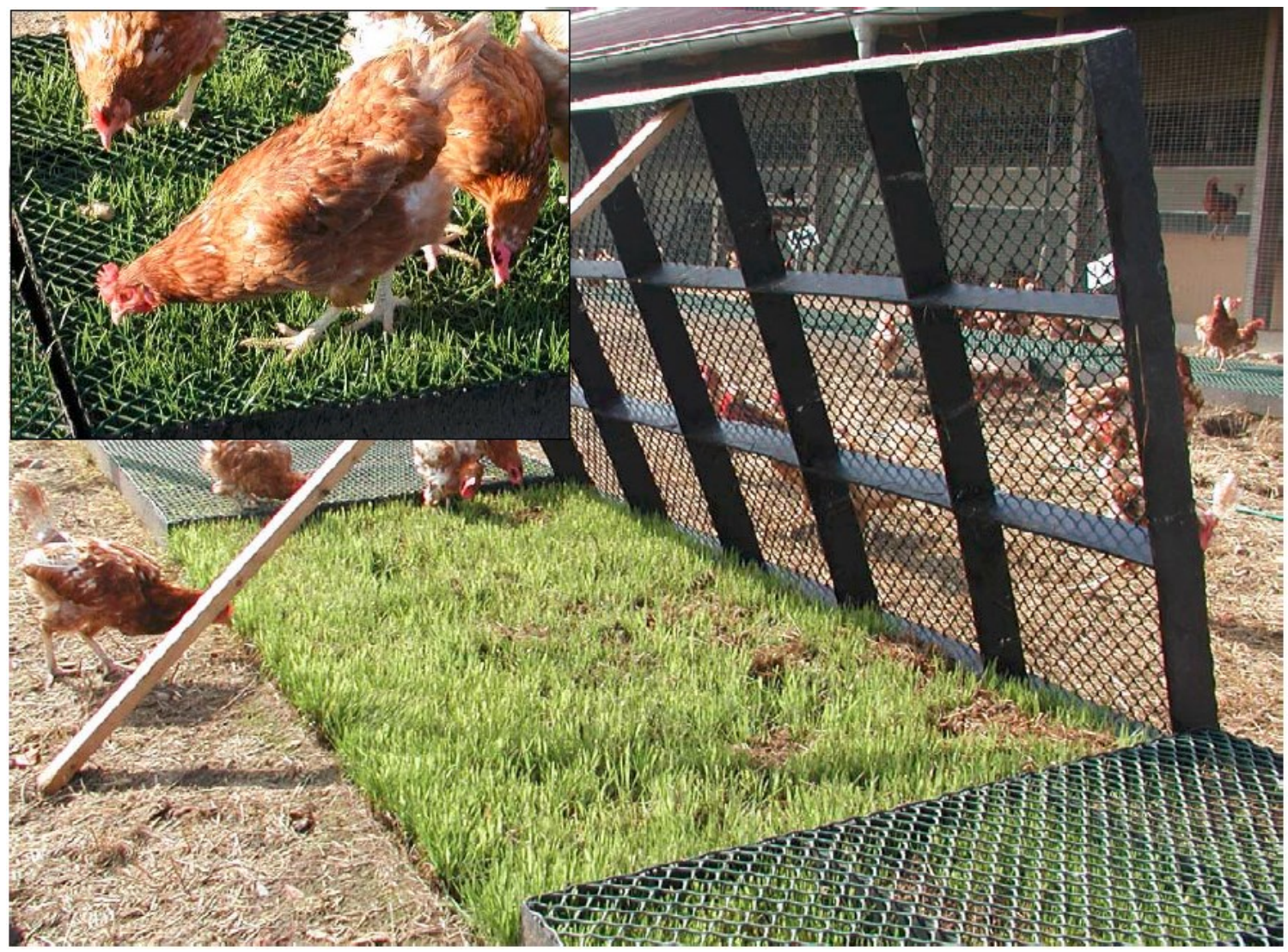

Figuur 4 Een afdekrooster voorkomt dat de begroeiing verdwijnt, de begroeiing zorgt ervoor dat $N$ niet uitspoelt (Elbe et al., 2005). 
De EGTOP (2012) adviseert om uitlopen te beplanten met tenminste 5 soorten planten uit tenminste drie plantfamilies, zoals meerjarige heesters, struiken, bomen en, waar lage dichtheden van bomen/struiken aanwezig zijn, weiland en/of eenjarige bodembedekkers. Een deel van de beplanting zou tevens moeten dienen als beschutting, aanvullend op kunstmatige structuren. Indien de begroeiing teveel is afgebroken (b.v. door overbegrazing), dan dient dit hersteld te worden door een lagere bezettingsdichtheid of een langere rusttijd van het perceel. Wisselbeweiding is daarbij niet per definitie de juiste oplossing, dit dient ruimer gezien te worden. Zo kan door het stimuleren van het gebruik van andere delen van de uitloop of het regelmatig oogsten van gewassen ook gezorgd worden voor een meer gespreid gebruik en daarmee een gespreide bemestingsdruk op de uitloop. Dichtbij de stal wordt aangeraden de bodem te bedekken met materiaal dat vocht absorbeert en regelmatig afgevoerd kan worden om zo de ziektedruk en overbemesting tegen te gaan.

De EGTOP (2012) adviseert tevens om voor het onderhoud van de vegetatie een verplichting in te stellen voor het oogsten en regelmatig verwijderen van materiaal. Waar overblijvende soorten domineren kan het als voeding gebruikt worden voor vee (gras, hout of ander organisch materiaal). Anderzijds kan bij oogstbare gewassen een rotatie systeem ingevoerd worden, om de kans op nutriëntenoverschotten te verminderen en zo risico's op vervuiling tegen te gaan. Of deze maatregelen de overbemesting volledig zullen tegengaan is te betwijfelen. Een goed onderhoud van de vegetatie zorgt er echter wel voor, dat de uitloop droger en schoner blijft, met minder druk van parasieten. De ziektedruk zal dan ook naar verwachting afnemen.

\subsubsection{Gebruik en afmetingen van de uitloop}

Zoals in paragraaf 2.1 is aangegeven bedraagt de gemiddelde omvang van Nederlandse bedrijven met uitloop circa 21.000 hennen (27 duizend voor vrije uitloop en 13 duizend voor biologisch). Bij dergelijke aantallen dieren is volgens Reichardt et al. (2004) te verwachten dat niet veel meer dan 5\% van de dieren gebruik maakt van de buitenuitloop. Vanwege de KAT-richtlijnen zijn de Nederlandse koppels allemaal opgedeeld in (sub)koppels van maximaal 6000 dieren. Bij deze groepsgrootte is volgens Reichardt et al. (2004) te verwachten dat circa $15 \%$ van de dieren gebruik maakt van de uitloop. Er is geen specifiek onderzoek uitgevoerd om te zien of een subkoppel, zoals door gazen afscheidingen gerealiseerd wordt, zich net zo gedraagt als een koppel van 6000 hennen in een kleinere stal. De door Reichardt et al. (2004) gevonden percentages voor het gebruik van de uitloop komen wel overeen met de door Dekker et al. (2010) gerapporteerde percentages voor koppels van circa 6000 hennen. Dit betrof subkoppels van 6000 uit grotere stallen.

Bij een gering gebruik van de uitloop kan men zich afvragen wat het nut is van het beschikbaar stellen van een groot oppervlakte van $4 \mathrm{~m}^{2} /$ hen. Een dergelijk groot oppervlak is immers veel minder goed te managen dan een kleiner oppervlak. Bij Rondeelstallen heeft men de buitenuitloop drastisch beperkt en er een ruimte van gemaakt, die goed controleerbaar is (overkapping, verharde vloer). Echter, deze uitloop voldoet niet meer aan de Europese Verordening (EG) Nr. 889/2008 (EG, 2008), waardoor de eieren niet verkocht kunnen worden als vrije uitloop of biologische eieren. Dit is de belangrijkste beweegreden voor pluimveehouders om zich te houden aan de $4 \mathrm{~m}^{2} /$ hen. Een ei uit uitloopsystemen of een biologische houderij brengt immers meer op dan een ei uit een scharrelsysteem.

Het merendeel van de bedrijven kan het gebruik van de uitloop door de hennen nog duidelijk verbeteren. Als eerste kan dit door een verbetering van de inrichting van de uitloop. Meer beschutting zal meer dieren naar buiten lokken. Bepaalde beplanting zal zeker meer dieren naar buiten lokken. Zo zal een bosrijke uitloop of een uitloop waarin mais groeit, meer hennen aantrekken. Ook kan het management verbeterd worden om hennen te stimuleren om naar buiten te gaan. Gedacht kan dan worden aan opvoeding van de hennen om de uitloop te gebruiken. Bij biologische hennen wordt reeds in de opfok een uitloop ter beschikking gesteld, bij reguliere hennen niet. Actieve maatregelen om de hennen naar buiten te krijgen worden doorgaans nauwelijks ondernomen en zijn deels ook niet toegestaan. Verstrekking van voer in de uitloop is bijvoorbeeld niet toegestaan in verband met het aantrekken van wilde vogels en het risico op ziekte-insleep (b.v. Aviaire Influenza). Andere maatregelen, zoals ruwvoerverstrekking wordt ook nagenoeg niet gedaan.

Er is nog zeer weinig aandacht voor de koppeling van stal en uitloop, met name het overgangsgebied tussen stal en uitloop. Praktijkervaringen geven aan dat een overdekte uitloop als 'buffer' tussen 
binnen en buiten, het gebruik van de buitenuitloop kan vergroten. Voor een belangrijk deel heeft dit te maken met het lichtniveau: hennen die vanuit een vrij donkere stal naar buiten gaan, worden door het felle licht verblind en zullen daardoor niet snel verder gaan. Een overdekte uitloop is wat lichter dan de stal, maar donkerder dan de uitloop en in deze ruimte kunnen de ogen van de hen zich aanpassen aan het hogere lichtniveau.

Voor zover bekend ligt er geen wetenschappelijke onderbouwing onder de wettelijke eisen ten aanzien van de afmetingen van de uitloop. Een kleinere uitloop zou het wellicht makkelijker maken om milieumaatregelen te nemen. Echter, dit geldt alleen als de uitloop fors kleiner zou worden. Uitgaande van een gebruik van de uitloop door $15 \%$ van de hennen, zou een evenredige verkleining betekenen dat per hen $0,6 \mathrm{~m}^{2}$ beschikbaar zou zijn. Bij een koppel van 6000 hennen zou dit $900 \mathrm{~m}^{2}$ zijn. Vanuit de eis van KAT dat er $2 \mathrm{~m}$ uitloop opening per 1000 hennen moet zijn, zou dit een uitloop zijn van minimaal $12 \mathrm{~m}$ breed en maximaal $75 \mathrm{~m}$ diep in geval van eenzijdige uitloop. Als de hennen aan beide zijden de stal uit kunnen wordt de uitloop minimaal 6 meter breed en 150 meter diep.

Er zijn een aantal nadelen aan het verkleinen van het totale uitloopoppervlak:

- gegeven het feit dat de hennen vooral binnen de eerste 10 van de stal blijven, zal een verkleining tot $15 \%$ van de huidige afmetingen voor het merendeel van de hennen een niet merkbare wijziging zijn. Er zal dus evenveel mest in de uitloop vallen als in de grotere uitloop. Het probleem van overbemesting is hiermee niet gewijzigd.

- doordat meer bedrijven aan de eisen van de kleinere uitloop kunnen voldoen, zullen meer scharrelbedrijven overschakelen naar uitloop. Landelijk gezien zal de overbemesting dus toenemen.

- $\quad$ een afmeting van $15 \%$ van de huidige afmeting is nog steeds een te groot oppervlak om volledig te kunnen beheersen.

- $\quad$ bij kleinere afmetingen zullen maatregelen als wisselbeweiding niet meer mogelijk zijn. Een kleiner oppervlak van de buitenuitloop zal dus alleen zinvol zijn, indien dit zodanig veel kleiner is, dat een volledige controle mogelijk is, bijvoorbeeld door overkapping en verharding van de volledige bodem. 
De bodem van uitlopen van legpluimvee wordt, zeker in de nabijheid van de stal, meer dan formeel toegelaten belast met mineralen uit dierlijke mest. Door een sterk wisselend en niet egaal gebruik van de uitloop is een exact getal niet te geven, metingen wijzen echter uit dat dichtbij de stal 3 tot 40 maal de toegestane hoeveelheid stikstof uit dierlijke mest terecht komt. Voor fosfaat ligt de overschrijding nog hoger. Daardoor is het risico op (te) hoge gehaltes van $\mathrm{N}$ en $\mathrm{P}$ in het grondwater hoog, evenals de kans op uit- en afspoeling van mineralen uit de uitloop.

De uitloop heeft naar verwachting een zeer beperkte bijdrage aan de emissie van stof, geur, methaan en ammoniak van legpluimveebedrijven. Metingen aan uitstoot van ammoniak uit de uitloop geven aan dat deze circa $5 \%$ betreft van de uitstoot uit de legstal bedraagt. Voor stof, methaan en geur zijn geen cijfers bekend

Gemiddeld hebben vrije uitloopbedrijven in Nederland een omvang van 27 duizend hennen, verdeeld in groepen van 6000 hennen. Biologische bedrijven hebben gemiddeld 13 duizend hennen, verdeeld in groepen van 3000 hennen. Bij deze omvang is te verwachten dat ongeveer $15 \%$ van de hennen de uitloop gebruikt. Dit gebruik kan verbeterd worden door verbetering van de inrichting van de uitloop en het management om de hennen te stimuleren er gebruik van te maken.

Het verdient aanbeveling de effectiviteit van maatregelen, om de overbelasting van de uitloop met mineralen te beperken, nader te onderzoeken.

Het kan dan gaan om mogelijkheden om de spreiding van de hennen en dus van de mest over de uitloop te verbeteren. Als dat gebeurt met natuurlijke begroeiing zullen de gewassen (een deel van) de mineralen vastleggen. Bij oogsten van die gewassen wordt een deel van de mineralen afgevoerd. In hoeverre deze maatregelen ook daadwerkelijk een substantiële bijdrage leveren is niet bekend.

Een andere optie is de ruimte dichtbij de stal zo in te richten, dat de bovenlaag regelmatig verwijderd kan worden. Als die toplaag op een dichte vloer/mat aangebracht is, kan overmatige belasting van de bodem met mineralen en lekwater voorkomen worden.

Het verkleinen van de uitloop, zal doorgaans niet leiden tot minder mest in de uitloop. Doordat meer bedrijven aan de eisen kunnen voldoen, zullen er meer bedrijven met uitloop komen, waardoor landelijk gezien het probleem van overbemesting zal toenemen. Verkleining van de uitloop heeft daarom alleen zin als hiermee een volledige controle van de overbemesting mogelijk is. Dit betekent in de praktijk een verkleining tot een format dat overkapt kan worden en een volledig harde bodem heeft, waardoor overbemesting niet meer mogelijk is.

Tot nut toe zijn er geen gegevens beschikbaar over effectiviteit en kosten van mogelijke maatregelen om overmatige belasting van de bodem met mineralen bij uitloophouderij van leghennen te voorkomen.

De huidige uitloophouderij bij leghennen is slechts in beperkte mate te vergelijken met de uitloophouderij bij eenden, zoals die in de 90-er jaren van de vorige eeuw voorkwam. De eenden werden gedurende een groot deel van het jaar permanent en met de hele koppel buiten gehouden. Bij de leghennen komt slechts een deel van de hennen buiten en zijn de hennen een groot deel van het etmaal (met name 's nachts) allemaal binnen. Daarnaast is de samenstelling van leghennenmest wezenlijk anders dan die van eendenmest. 


\section{Literatuur}

Aarnink AJA, Hol JMG, Beurskens AGC and Wagemans MJM (Agrotechnology \& Food Innovations B.V.), 2005. Ammoniakemissie en mineralenbelasting op de uitloop van leghennen. Rapport 337, 27 pag.

Bestman M, 2006. Mineralenbelasting in de kippenuitloop. Louis Bolk Instituut, Biologische Pluimveehouderij 2: 2.

Bikker P, Harn J van, Groenestein CM, Wit J de, Bruggen C van and Luesink HH, 2013. Stikstof- en fosforexcretie van varkens, pluimvee en rundvee in biologische en gangbare houderijsystemen. Wageningen : Wettelijke Onderzoekstaken Natuur \& Milieu, (WOt-werkdocument 347) - 43 p.

Burgt GJvd and Bestman M, 2009. Mineralenbelasting van de kippenuitloop; Kippenuitloop Gezond en Groen. Acta Agriculturae Scandinavica. Section A, Animal Science. LBI Publicatie LV76, 30 pag.

CBS, PBL, Wageningen UR, 2013. Macroparameters in ondiep grondwater, 1985-2012 (indicator 0273, versie 06, 18 december 2013). www.compendiumvoordeleefomgeving.nl. CBS, Den Haag; Planbureau voor de Leefomgeving, Den Haag/Bilthoven en Wageningen UR, Wageningen.

CBS, PBL, Wageningen UR, 2008. Fosfaatverzadiging landbouwgronden (indicator 0267, versie 04, 20 juni 2008).www.compendiumvoordeleefomgeving.nl. CBS, Den Haag; Planbureau voor de Leefomgeving, Den Haag/Bilthoven en Wageningen UR, Wageningen.

De Buisonjé F, Hannink NGJ, Vunderink G, Pouls F, Mosquera Losada J and Aarnink AJA (Animal Sciences Group), 2009. Maatregelen ter vermindering van fijnstofemissie uit de pluimveehouderij; effect van een oliefilm op het strooisel in volièrehuisvesting voor leghennen [Measures to reduce fine dust emissions from poultry houses; effect of an oil film on the litter in aviary housing for layers]. 195.

Den Boer DJ, JA Reijneveld, JJ Schröder, JC van Middelkoop, 2012. Mestsamenstelling in Adviesbasis Bemesting Grasland en Voedergewassen. Commissie Bemesting Grasland en Voedergewassen. Bemestingsadvies, Rapport 1, 24 pag.

Dekker SEM, Aarnink AJA, Boer IJMd and Groot Koerkamp PWG (Wageningen UR Livestock Research), 2010. Milieubelasting van drie biologische volièrebedrijven voor leghennen. Rapport 360, 46.

Dekker SEM, Aarnink AJA, Boer IJMd and Groot Koerkamp PWG, 2012. Total loss and distribution of nitrogen and phosphorus in the outdoor run of organic laying hens. British Poultry Science, 53, 731-740.

EG, 2008. Verordening (EG) Nr. 889/2008 van de commissie van 5 september 2008 tot vaststelling van bepalingen ter uitvoering van Verordening (EG) nr. 834/2007 van de Raad inzake de biologische productie en de etikettering van biologische producten, wat de biologische productie, de etikettering en de controle betreft. PB L 250 van 18.9.2008: 1-122.

EG 1991. Verordening (EEG) Nr. 1274/91 van de commissie van 15 mei 1991 houdende bepalingen ter toepassing van Verordening (EEG) nr. 1907/90 van de Raad betreffende bepaalde handelsnormen voor eieren. PB L 121 van 16.5.1991: 1-28.

EGTOP/4/2012, Report On Poultry, adopted on 20-21 June 2012. Expert Group for Technical Advice on Organic Production (EGTOP). European Commission Directorate-General for Agriculture and Rural Development, Directorate H. Sustainability and Quality of Agriculture and Rural Development. H.3. Organic farming (www.organic-farming.europe.eu). 39 pages.

Elbe U, Ross A and Steffens G, 2005. Freilandhaltung von Legehennen: Empfehlungen zum NährstoffManagement im Grünauslauf. Gut-Frohberg, Sachsen. 4.

KAT, 2011. Verein für kontrollierte alternative Tierhaltungs-formen e.V. (KAT). KAT handleiding voor legbedrijven, Scharrel- en vrije-uitloophouderij, Biologische productie. http://www.was-steht-aufdem-ei.de.

Meda B, Flechard CR, Germain K, Robin P, Walter C, Hassouna M, 2012. Greenhouse gas emissions from the grassy outdoor run of organic broilers. Biogeosciences, 9, pp. 1493-1508.

Mosquera J, Hol JMG, 2012. Emissiefactoren methaan, lachgas en PM2,5 voor stalsystemen, inclusief toelichting. Rapport 496, Wageningen UR Livestock Research, Lelystad.

Lippmann J (Sächsisches Landesamt für Umwelt, Landwirtschaft und Geologie), 2011. Bewertung der Bodenhaltung von Legehennen mit Auslauf hinsichtlich Stickstoffdynamik mit Bezug zu Wald, 
Geruchs- und Staubemissionen. Schriftenreihe des LfULG. Schriftenreihe des LfULG, Heft 27/2011, 118.

Reichardt W, Mußlick M, Gayer P and Hochberg H, 2004. Auslaufnutzung. In: Evaluierung alternativer Haltungsformen für Legehennen; Abschlussbericht zum Gemeinschaftsprojekt der Landesanstalten für Landwirtschaft der Freistaaten Bayern, Sachsen und Thüringen. U Bergfeld. Bayerischen Landesanstalt für Landwirtschaft, 123-138.

Zeelen $\mathrm{H}$, 1995. Uitloop leghennen belastend voor milieu. 25, 21.

Zimmerman KL, Mares AMHM, Riensema CJ and Horne PLMv (Landbouw Economisch Instituut), 1990. De afzetperspectieven van Nederlands tamme-eendevlees op middellange termijn. Mededeling. 437, Med. No. 437, 149 pag.

Zorn W, Lippmann J, Gayer P, Schröter H and Reichardt W, 2004. Nährstoffeintrag in den Boden. In: Evaluierung alternativer Haltungsformen für Legehennen; Abschlussbericht zum Gemeinschaftsprojekt der Landesanstalten für Landwirtschaft der Freistaaten Bayern, Sachsen und Thüringen. U Bergfeld. Bayerischen Landesanstalt für Landwirtschaft, 139-151. 

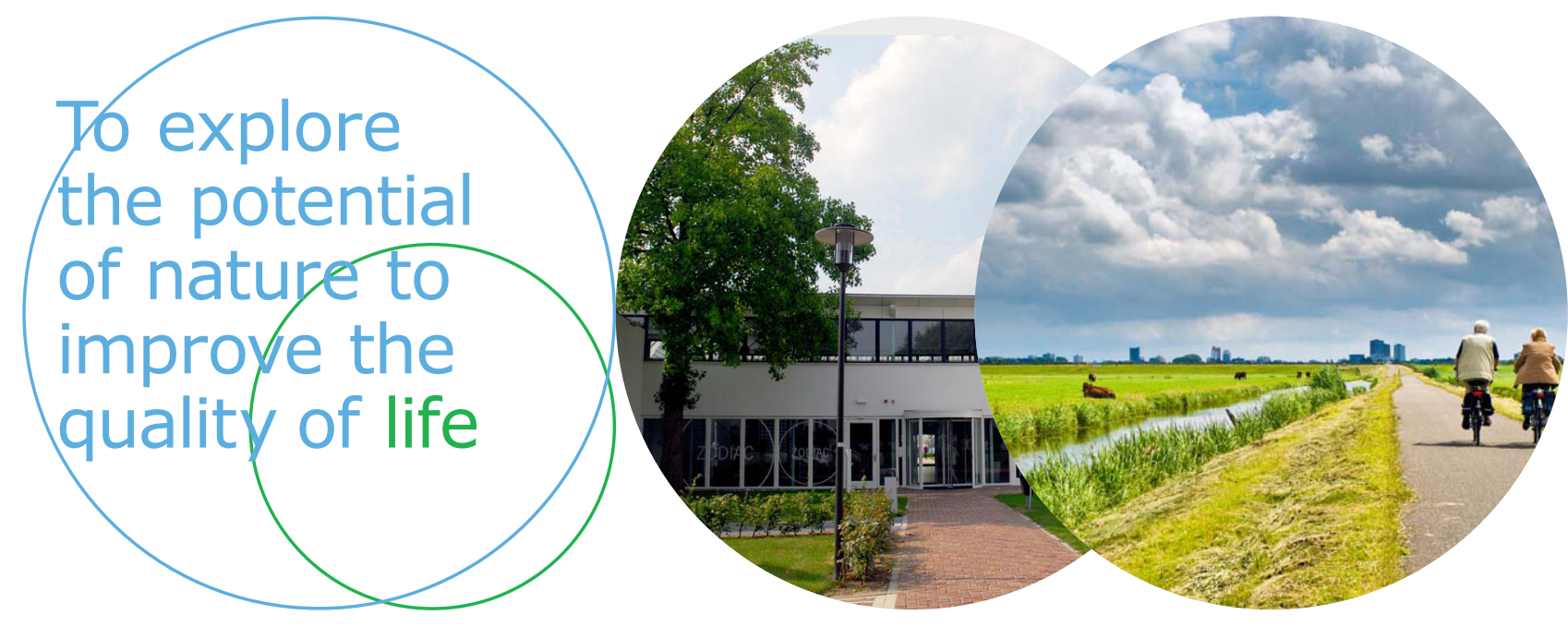

Wageningen UR Livestock Research Postbus 338

6700 AH Wageningen

T 0317483953

E info.livestockresearch@wur.nl www.wageningenUR.nl/livestockresearch
Wageningen UR Livestock Research ontwikkelt kennis voor een zorgvuldige en renderende veehouderij, vertaalt deze naar praktijkgerichte oplossingen en innovaties, en zorgt voor doorstroming van deze kennis. Onze wetenschappelijke kennis op het gebied van veehouderijsystemen en van voeding, genetica, welzijn en milieu-impact van landbouwhuisdieren integreren we, samen met onze klanten, tot veehouderijconcepten voor de $21 \mathrm{e}$ eeuw.

De missie van Wageningen UR (University \& Research centre) is 'To explore the potential of nature to improve the quality of life'. Binnen Wageningen UR bundelen 9 gespecialiseerde onderzoeksinstituten van stichting DLO en Wageningen University hun krachten om bij te dragen aan de oplossing van belangrijke vragen in het domein van gezonde voeding en leefomgeving. Met ongeveer 30 vestigingen, 6.000 medewerkers en 10.000 studenten behoort Wageningen UR wereldwijd tot de aansprekende kennisinstellingen binnen haar domein. De integrale benadering van de vraagstukken en de samenwerking tussen verschillende disciplines vormen het hart van de unieke Wageningen aanpak. 